\title{
Miscellaneous Chemical Basin Treatability Study: An Analysis of Passive Soil Vapor Extraction Wells (PSVE)
}

by

B. Riha

Westinghouse Savannah River Company

Savannah River Site

Aiken, South Carolina 29808

J. Rossabi

This paper was prepared in connection with work done under the above contract number with the U.S. Department of Energy. By acceptance of this paper, the publisher and/or recipient acknowledges the U.S. Government's right to retain a nonexclusive, royalty-free license in and to any copyright covering this paper, along with the right to reproduce and to authorize others to reproduce all or part of the copyrighted paper. 


\section{DISCLAIMER}

This report was prepared as an account of work sponsored by an agency of the United States Government. Neither the United States Government nor any agency thereof, nor any of their employees, makes any warranty, express or implied, or assumes any legal liability or responsibility for the accuracy, completeness, or usefulness of any information, apparatus, product, or process disclosed, or represents that its use would not infringe privately owned rights. Reference herein to any specific commercial product, process, or service by trade name, trademark, manufacturer, or otherwise does not necessarily constitute or imply its endorsement, recommendation, or favoring by the United States Government or any agency thereof. The views and opinions of authors expressed herein do not necessarily state or reflect those of the United States Government or any agency thereof.

This report has been reproduced directly from the best available copy.

Available to DOE and DOE contractors from the Office of Scientific and Technical Information, P.O. Box 62, Oak Ridge, TN 37831; prices available from (615) 576-8401.

Available to the public from the National Technical Information Service, U.S. Department of Commerce, 5285 Port Royal Road, Springfield, VA 22161. 


\section{DISCLAIMER}

Portions of this document may be illegible electronic image products. Images are produced from the best available original document. 
WSRC-TR-97-00405

Revision 1.0

Publication Date: December 1997

Miscellaneous Chemical Basin Treatability Study: An Analysis of Passive Soil Vapor Extraction Wells (PSVE) (U)

B. D. Riha

J. Rossabi

Westinghouse Savannah River Company

Savannah River Site

Aiken, SC, 29808

Prepared for the US Department of Energy under Contract DE-AC09-96SR18500 


\section{Contents}

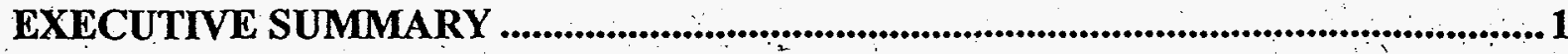

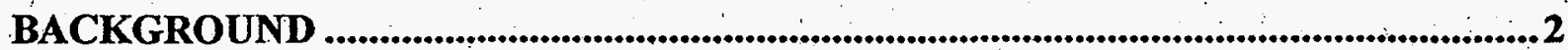

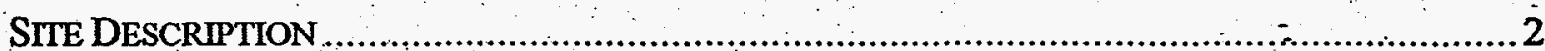

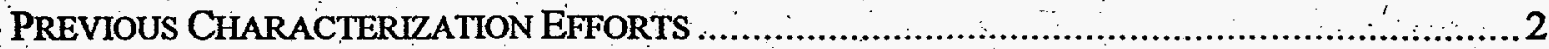

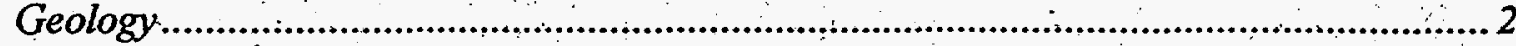

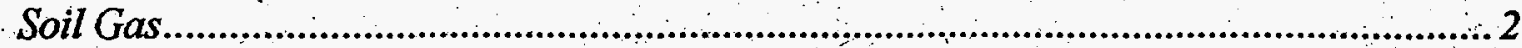

Sediment Sampling Results .................................................................................

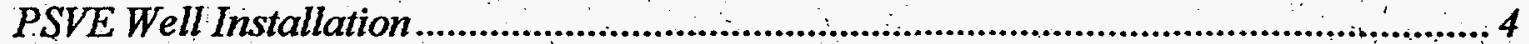

TECHNOLOGY DESCRIPTION - BAROMETRIC PUMPING

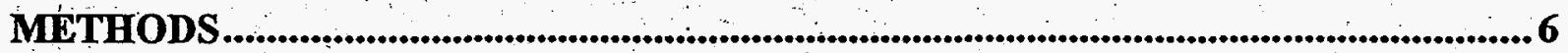

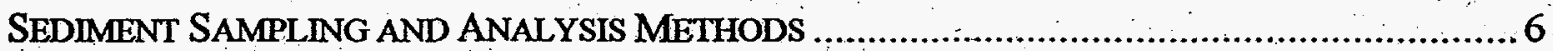

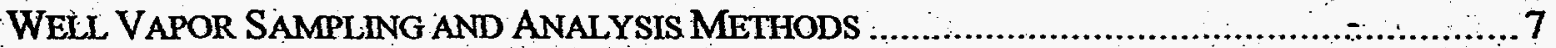

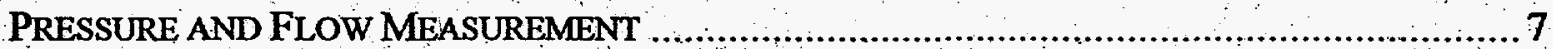

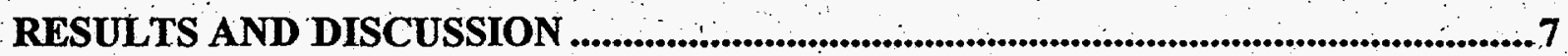

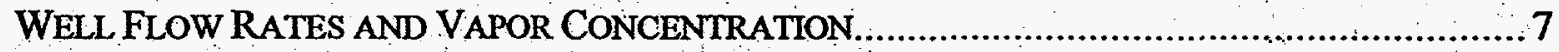

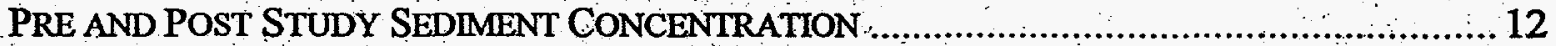

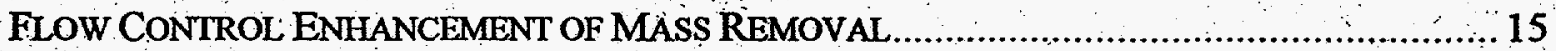

SOLAR HEAT ENHANCEMENT OF MASS REMOVAL 15

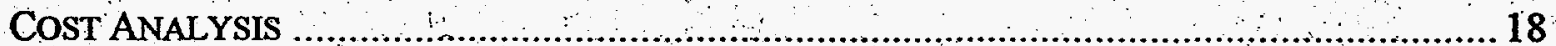

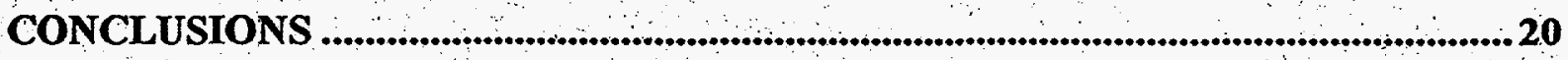

$\because \quad \cdots \quad \cdots$

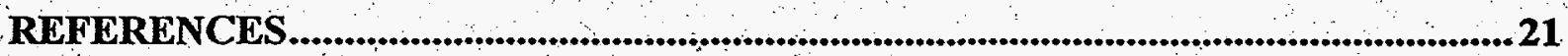

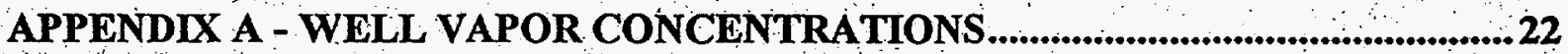




\section{List of Tables}

Table 1 - Statistics from Pressure and Flow Measurements at CPT-MCB-3A ...................9

Table 2- Pre and Post Study Sediment Concentrations $(\mu \mathrm{g} / \mathrm{kg})$................................. 15

Table 3 - Energy Required for Heating Subsurface in PSVE Volume of Influence.:...........16

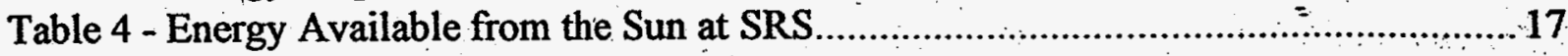

Table 5 - Passive Steam Injection Rates ............................................................ 17

Table 6 - Mass Removed by PSVE from 10/7/96 to 11/7/97 and Projected Mass Removed in 10 Years ................................................. 19

Table 7 - Total TCE Mass Removed and Estimated Cost for Removal .............................. 19

\section{List of Figures}

Figure 1 - Miscellaneous Chemical Basin Vadose Zone Well and Soil Boring Locations ..... 5

Figure 2 - Typical Pressure and Flow Response for Well CPT-MCB-3 ......................... 8

Figure 3 - Estimated Flow Rate and Volume Removed with Flow Enhancement................8

Figure 4 - Well Vapor Concentration Trends and Exponential Fits............................... 10

Figure 5 - Pre and Post-Study Soil Gas Plumes ....................................................... 11

Figure 6 - Pre and Post-Study TCE Sediment Concentration Profiles (Locations 1-3)........ 13

Figure 7 - Pre and Post-Study TCE Sediment Concentration Profiles (Locations 4-5) .... 14

Figure 8 - Time History of Solar Heat Collector Temperatures ....................................... 18 


\section{Executive Summary}

A passive soil vapor extraction (PSVE) treatability study at the Miscellaneous Chemical Basin (MCB) of the Savannah River Site (SRS) has been progressing since September 1996. During this time more than 100 pounds of chlorinated organic contaminants have been removed by natural barometric pumping of wells fitted with BaroBall ${ }^{\mathrm{TM}}$ valvés (low pressure check valves). In addition, contour maps of the vadose zone contaminant gas plume made before the study and after 1.1 years of operation show a significant decrease in the extent of the gas plume and identify the source location. From extrapolations of the exponentially declining contaminant concentrations measured in the wells, all of the wells except those in the source zone will be below 1 ppmv in apptoximately three years simply using PSVE. The source zone wells will be below 1 ppmv in approximately 10 years using no additional remediation method.

Mass removal during this time frame is attributed to residual contamination in the coarse grained material and some contaminant mass transfer from the finer grained zones to coarse zones where the majority of the PSVE flow is achieved. Removal from the fine grained sediments will be limited by the mass transfer from these zones to the coarse grained zones.

PSVE requires minimal operation and maintenance costs during its lifetime of operation (more than 10 years). Monthly well vapor sampling and analysis requires approximately 8 hours per month. For this study, characterization and well installations at 25 locations using cone penetrometer technology (CPT) were performed in three weeks for approximately $\$ 60 \mathrm{~K}$. The characterization included continuous geologic profiles through the entire vadose zone, depth-discrete gas sampling for volatile organic contaminants, and sediment samples.

To remediate the source zones more quickly, passive heat injection is proposed as an extension to the treatability study. From previous testing and theoretical calculations, the subsurface can be heated using a passive solar collector and passive soil vapor injection. If the subsurface têmperature can be raised by $10^{\circ} \mathrm{C}$, contaminant removal rate will approximately double.

The PSVE system is performing well in a cost-effective manner. It is recommended that this system be allowed to continue operating for at least another year to verify the anticipated contaminant removal rates using passive heat injection and to evaluate removal effectiveness in the lower permeability zones. 


\section{Background}

\section{Site Description}

The Miscellaneous Chemical Basin waste unit is located in the northwest portion of SRS, approximately 1.5 miles south of the $3 / 700$ Area operations and 3 miles east of the SRS boundary. Little information is available on the historical operations of the basin. It is thought to have received liquid wastes from the 3/700 Area operations, consisting of waste solvent and used oil. It is also believed that partially full drums were emptied at this site.

The basin boundaries have been estimated based on site photographs. The MCB was approximately 20 by 20 feet in length and width, and approximately 1 foot deep. Photographs indicate that the basin received liquid chemical wastes from about 1956 to 1974 and was located in a shallow borrow pit covering a small portion of the waste unit. In 1974 the basin was re-graded and the original near-surface basin sediments were distributed in a field at the site with approximate dimensions of 350 by 350 feet. The site is currently covered by weeds, grasses and small pine trees. The surface of the waste unit exhibits a slight slope of approximately 3 percent to the east-southeast.

\section{Previous Characterization Efforts}

Previous screening activities conducted at the MCB include continuous geologic profiles, soil gas surveys, soil confirmation sampling, and groundwater monitoring as discussed below.

\section{Geology}

The Savannah River Site is underlain by a thick wedge (approximately $1000 \mathrm{ft}$ ) of unconsolidated Tertiary and Cretaceous sediments consisting primarily of sands, clayey sands, and sandy clays. Two significant fine grain layers in the vadose zone at the Miscellaneous Chemical Basin are located at approximately. $0-15 \mathrm{ft}(330 \mathrm{ft} \mathrm{msl})$ and $75-85 \mathrm{ft}$ $(260 \mathrm{ft} \mathrm{msl})$ below ground surface. The water table at the site is at approximately $120 \mathrm{ft}(220$ $\mathrm{ft}$ msl) below the ground surface.

The CPT friction ratio logs collected in 1996 indicate a significant fine grained sediment layer which occurs approximately 5 to 15 below the surface. Below this layer is a coarse grained (sandy) layer approximately $50 \mathrm{ft}$ thick with a few narrow silty layers. Below this interval is an interbedded clayey/silty/sandy zone ranging in thickness from $5 \mathrm{ft}$ on the northwest to $15 \mathrm{ft}$ on the southeast of the investigated area. The sediment layering dips to the southeast and tends to follow the surface contour. The boundaries of the area investigated is shown in Figure 1.

\section{Soil Gas}

Two phases of shallow soil vapor sampling were conducted in 1986 with 120 samples collected from a depth of 1.5 to $2 \mathrm{ft}$ on approximately $20 \mathrm{ft}$ centers. Sampling results indicated the presence of trichloroethylene (TCE) and perchloroethylene (PCE) in 
concentrations up to $5.5 \mathrm{ppmv}$ and $44.8 \mathrm{ppmv}$, respectively. Trichloromethane and cis- 1,2 dichloroethylene (cis-1,2 DCE) were also detected at concentrations up to $0.02 \mathrm{ppmv}$ and $0.30 \mathrm{ppmv}$, respectively. The highest concentrations were detected north of the basin and vadose zone contaminant migration appeared to be in a north-northeasterly direction.

During September and October of 1996, in support of the treatability study, a total of 128 soil gas samples were collected at varying depths between 15 and $110 \mathrm{ft}$ at 25 locations using a CPT soil gas method described in the characterization report (Riha et al., 1996).' Sampling depths were chosen during the CPT push by analyzing the friction ratio logs and determining permeable locations near the clayey zones. Contaminants are expected to be located in the fined grained sediments but it is difficult to obtain sufficient soil gas flows for sampling in these zones. Soil gas samples were also taken near the center of the $50 \mathrm{ft}$ thick sandy zone to determine the vertical distribution of soil gas concentrations. A site map showing soil gas and well locations is presented in Figure 1.

The results from the initial soil gas analysis are presented in the characterization report (Riha et al., 1996). These results were used to locate the PSVE wells for the treatability study. Concentrations ranged from $28.7 \mathrm{ppmv}$ carbon tetrachloride $\left(\mathrm{CCL}_{4}\right), 140 \mathrm{ppmv}$ TCE and 99.5 ppmv PCE in the vicinity of CPT-MCB-4 to non-detect levels at the outer perimeter of the basin. Soil gas concentrations are generally highest in the vicinity of the $15-20 \mathrm{ft}$ depth interval at the MCB. Concentrations are highest for TCE and the center of the plume is located around CPT-MCB-4, 13, and 22. Soil gas concentrations decrease and spread laterally with depth. The lateral soil gas migration tends toward the southeast away from CPT-MCB-4.

\section{Sediment Sampling Results}

In 1987 and 1989, soil samples collected from soil borings, monitoring wells, and test pits were analyzed and found to contain VOCs (e.g. TCE, PCE, chlorobenzene, chloroform, and trans-1,2-DCE) from just below surface (0-2 feet) to depths of approximately 225 feet. However, the highest concentrations appear to occur within the upper 120 feet (vadose zone). Analysis of the groundwater since 1985 show TCE and PCE levels in excess of the EPA Maximum Contaminant Levels (MCLs) for drinking water standards in 9 of the 13 monitoring wells which surround the basin. Depth to the water table in the vicinity of the MCB is approximately 120 feet below surface; therefore removal of the VOCs within the vadose zone is considered a priority.

Five locations at the MCB were sampled for sediment analyses in 1996 . Continuous 2 foot long core samples were collected at CPT-MCB-S1 from $2 \mathrm{ft}$ to a depth of $82 \mathrm{ft}$ to determine the vertical extent of the sediment contamination. This location corresponds to the highest soil gas concentrations during the current characterization effort. Well CPT-MCB-4 was installed in this borehole. The core was also inspected visually and compared to the CPT logs which provided a good correlation for lithology determination with CPT logs at the site.

Contaminants in the sediment samples appear primarily in the two zones of fine grained sediments. The highest concentrations for two of the sampling locations were measured in 
the lower layer $(74-80 \mathrm{ft})$ which has a higher clay content than the upper zone at $5-15 \mathrm{ft}$. Lower concentrations of TCE were measured in the sandy/silty layers.

Sediment VOC concentrations at CPT-MCB-S2 were high in the upper clay layer in the 4-8 $\mathrm{ft}$ depth $(231-10,735 \mu \mathrm{g} / \mathrm{kg}$ PCE). Duplicate samples in this range did not correlate well which may be attributed to the heterogeneous nature of the sediments. The concentration in the lower clay zone $(74-80 \mathrm{ft})$ was $123 \mu \mathrm{g} / \mathrm{kg}$ (TCE) indicating the contaminants are still trapped in the upper clay layer $(5-15 \mathrm{ft}$ ). Sediment concentration's in CPT-MCB-S3 follow a similar trend with higher concentrations in the shallow clay zone $(5-15, \mathrm{ft})$ and lower concentrations in the deeper clay zone $(74-80 \mathrm{ft})$.

Sediment concentrations at CPT-MCB-S4 and S5 are higher in the deeper clay zone (74-80 $\mathrm{ft}$ ). The higheist VOC sediment concentration in CPT-MCB-S4 was $5,325 \mu \mathrm{g} / \mathrm{kg}$. PCE at 69 ft. However, VOC contaminants in the duplicate sample were not detected. This discrepancy may be attributed to the heterogeneity of the sand/silt/clay layers in this region.

The results from the sediment samples suggest a contaminant source was released in the area near CPT-MCB-S2 and CPT-MCB-4. Sediment VOC contamination is consistent with releases of PCE and TCE to the subsurface over an 18 year period. The contaminants have migrated down through the upper clay layer and to the southeast into the lower clay layer.

\section{PSVE Well Installation}

Twenty five vadose zone wells were installed at the MCB in the same push hole as the CPT geophysical and soil gas pushes. The wells were installed by threading a steel push tip onto the PVC screen and pushing the tip with the steel CPT rods in the center of the PVC, effectively pulling the PVC well down with the push tip. The 6 inch long steel push tip remained in the ground.

The wells were installed so the formation was compressed against the outer surface of the casing and screen, leaving no annular space. The potential for vertical migration is minimal because the well material provides no channels to transport liquids. The compression of the formation against the walls of the well reduces gravity flow along the casing in contrast with the flow processes occurring in the natural materials of the formation. All vadose zone wells were installed to a depth that did not breach the water table; the maximum termination depth of the vadose zone wells was greater than 10 feet above the water table. Concrete pads were installed around the wells at the surface. 


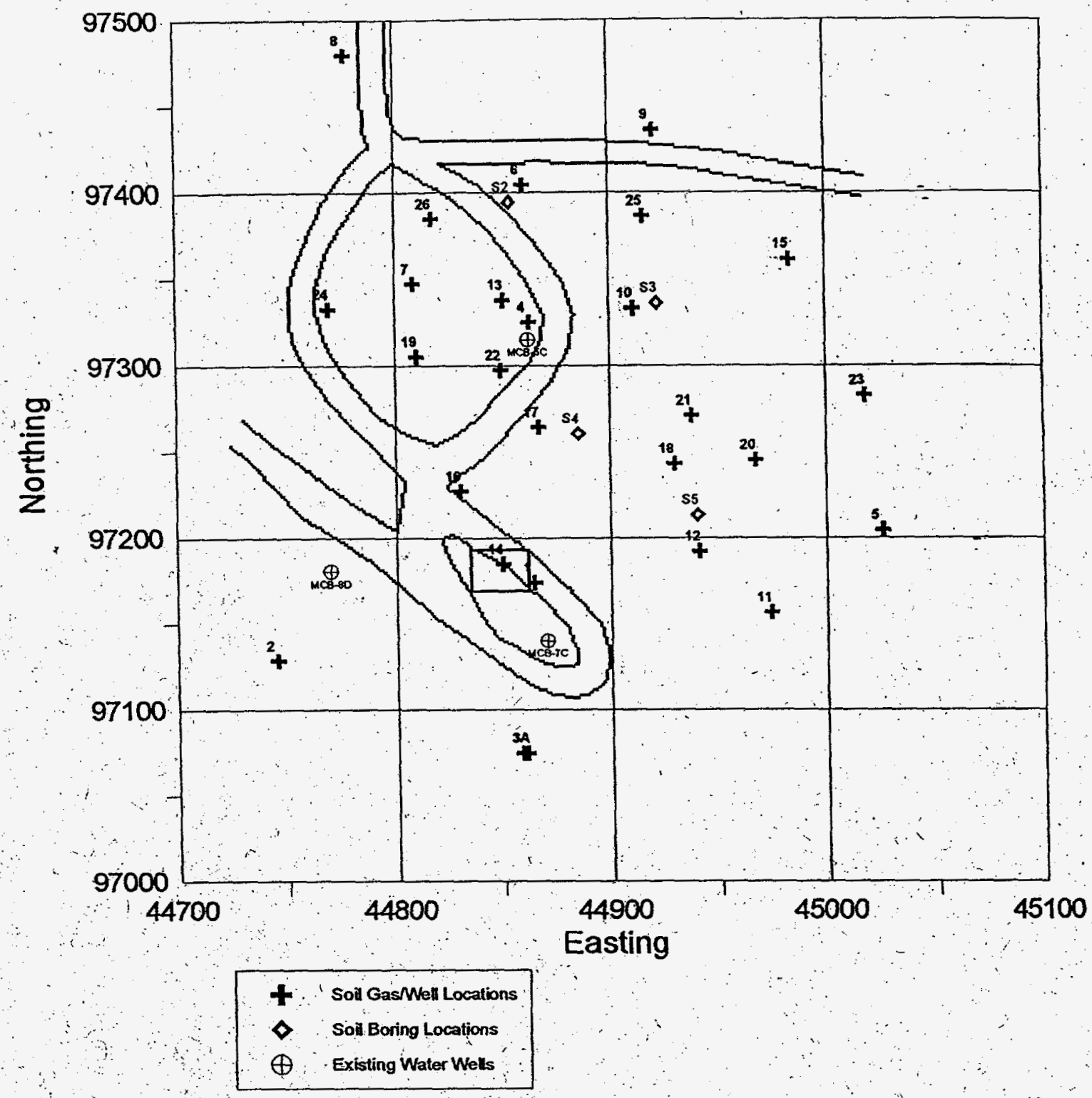

Figure 1-Miscellaneous Chemical Basin Vadose Zone Well and Soil Boring Locations

\section{Technology Description - Barometric Pumping}

Natural atmospheric pressure fluctuations are transmitted through the unsaturated subsurface, however, these pressure waves are damped and delayed in phase to degrees dependent on the effective vertical permeability of the formation. As a result of the attenuation and delay of the transmitted pressure wave, at a given time the atmospheric pressure at the surface and the soil gas pressure in the subsurface will be different. If these two zones are directly connected (by a vadose zone well), the pressure differential will result in a flow either into or out of the well. If the subsurface contains VOCs in the gas phase, flow out of the well will result in removal of the contaminants from the subsurface without mechanical pumping. This phenomena has been observed for more than a century, (the first reference in the literature is an article in Science, 1897 by Fairbanks) but has only recently been proposed for 
environmental remediation. The technology is also known as barometric pumping. The duration of flow events (either flow into the well or flow out of the well) can be as long as three days continuously but, as expected by mass balance considerations, the average time of flow in is equal to the average time of flow out. The flow rates for a typical well are generally low (.1 to $10 \mathrm{scfm}$ ) but if the concentration of the contaminant in the gas phase is high, mass removal by this process can be significant. Rátes as high as 1 tơ $2 \mathrm{~kg} /$ day/well have been observed near sources in the A/M Area of SRS. Mass removal can be enhanced using low cost or natural techniques. Enhancements to PSVE include the addition of wind powered turbine vacuum pumps, installation of one way mechanical valves to prevent dilution of the contaminated soil gas by clean air from the surface, and solar heat injection to raise vapor pressures and the partitioning of the VOCs from the liquid or aqueous phases to the gas phase.

The BaroBall is a device devèloped and patented by WSRC specifically for barometric pumping applications. It uses a light weight ball in a conical seat to permit gas flow in one direction with a minimal pressure requirement (approximately $1:$ millibar) but effectively prevents gas flow in the reverse direction. Depending on the configuration, the BaroBall can be used to allow contaminated soil gas out of a well and prevent clean air from diluting the soil gas in the subsurface (standard mode of operation), to inject air and/or nutrients into the subsurface to enhance bioremediation, to control or confine the movement of a subsurface gas phase plume in the vadose zone, or to passively transfer solar heated, water-saturated air into the subsurface to enhance volatilization in the subsurface. The BaroBall device is attached directly to the top of the well casing at the surface.

Application of this technology is directed to any site where volatile substances (chlorinated solvents, petroleum products, etc.) have contaminated the vadose zone. Natural pressure fluctuations and their damped and delayed transmission through the subsurface occur in all environments but are particularly well-suited to sites with large vadose zones or substantial low permeability layers that increase the damping and delay of the atmospheric pressure signal.

Field scale studies have been ongoing at SRS, the Hanford site and the Idaho National Engineering Lab for approximately five years, and a field scale implementation of the technology for control of subsurface methane migration using a combination of passive injection and extraction was recently installed at a landfill in Richmond County, Georgia. The MCB treatability study is the first implementation to directly target the removal of the vadose zone source term:

\section{Methods}

\section{Sediment Sampling and Analysis Methods}

At each soil sampling depth, the cone penetrometer truck using a MOSTAP® soil sampler collected a core sample of approximately 1 " in diameter and 24 " long. Once the sample was brought to the surface, a 2 cc plug sample was collected using a modified plastic syringe. 
The plug was transferred to a $22 \mathrm{ml}$ vial containing $5 \mathrm{ml}$ of nano-pure water and the vial was sealed with a crimped septum top for later head space analysis. Duplicate samples were collected at each depth and all samples were stored at $4^{\circ} \mathrm{C}$ until analysis.

Each sample was weighed and then analyzed on the HP 5890 Series gas chromatograph using an automated head space sampler for equivalent water concentrations. Mass soil concentrations ( $\mathrm{ppb}, \mu \mathrm{g} / \mathrm{kg}$ ) were calculated based on an equal head space volume from $7 \mathrm{ml}$ of water standards and $7 \mathrm{ml}$ of water/soil matrix and were corrected for the mass difference between the soil and water. The gas chromatograph was calibrated using stock solutions of neat (pure) solvents diluted to specific concentrations. The standard concentrations used for each head space sample run were $3,5,10,50,100,500$, and $1,000 \mathrm{ppb}(\mu \mathrm{g} / \mathrm{ml})$. The samples were analyzed for Vinyl Chloride, Freon-11, Freon-113, 1,1-DCE, Trans-DCE, Cis$\mathrm{DCE}, \mathrm{CHCl}_{3}, \mathrm{TCA}, \mathrm{CCl}_{4}, \mathrm{TCE}$, and $\mathrm{PCE}$. The record of the brand name and lot number of the standards was logged in the GC log book along with the amount used, date and person making the stock solutions.

\section{Well Vapor Sampling and Analysis Methods}

Concentration measurements were made on the vadose zone wells approximately monthly during barometric pumping outflow events. Well vapor was sampled and analyzed using a Bruel and Kjaer Módel 1302 photo acuoustic infrared gas analyzer. The instrument was calibrated to measure TCE , $\mathrm{PCE}, \mathrm{CCl}_{4}$, and $\mathrm{CO}_{2}$ and periodic samples were obtained in Tedlar sample bags and analyzed on an HP 5890 series GC for instrument verification.

\section{Pressure and Flow Measurement}

Pressure and flow measurements were recorded using either a Campbell Scientific $\otimes$ CR10 or Z-World $\otimes$ data logger. Barometric pressure was measured with a Vaisala® PTA 427 pressure transmitter with a range of $800-1060 \mathrm{mbar}$. Differential pressure was measured with an Omega@ PX163 low pressure transducer with a range of \pm 5 inches of water. Gas:

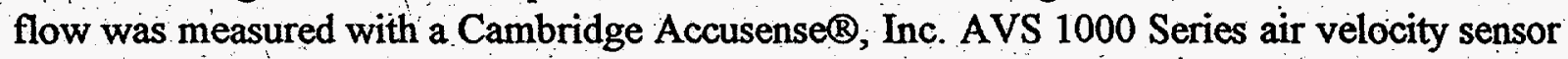
with a range of $1000 \mathrm{fpm}$. For all parameters, point measurements were made at 15 minute intervals.

\section{Results and Discussion}

\section{Well Flow Rates and Vapor Concentration}

Well vapor flow and concentration measurements show mass removal from the vadose zone at the Miscellaneous Chemical Basin. Pressure, and flow rates were measured on several wells at the site with CPT-MCB-3 having the longest history of measurements. A typical pressure and flow response during 4 days of measurements is shown in Figure 2. Wells CPT-MCB-3 and 3A are $3 \mathrm{ft}$ apart and have screen lengths at $57-72 \mathrm{ft}$ and $80-95 \mathrm{ft}$ respectively. The flow measurements were made on the deeper well and pressure measurements were made on the shallower well. These data were used to create a 
pressure/flow correlation for long term flow estimation. Pressure measurements were made on these wells for 61 days and the estimated flow rates for this period are shown in Figure 3. The cumulative volume of soil gas removed during periods of venting from the vadose zone was $100,356 \mathrm{ft}^{3}$ and is shown by the cumulative curve on the chart. This removal is based on the assumption that air flow is not allowed to enter the well by using a Baroball. Statistics from this period are presented in Table 1.

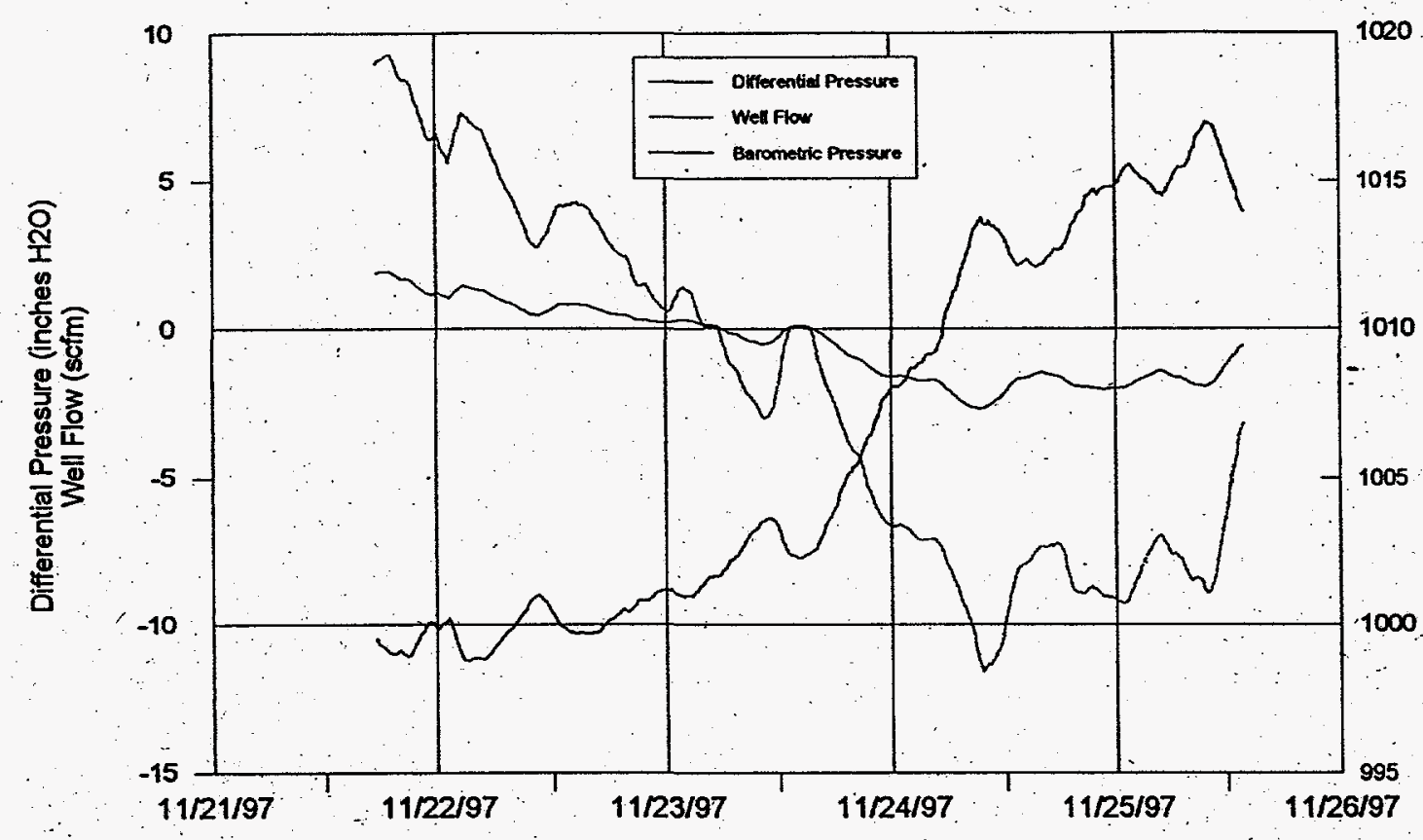

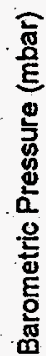

Figure 2-Typical Pressure and Flow Response for Well CPT-MCB-3

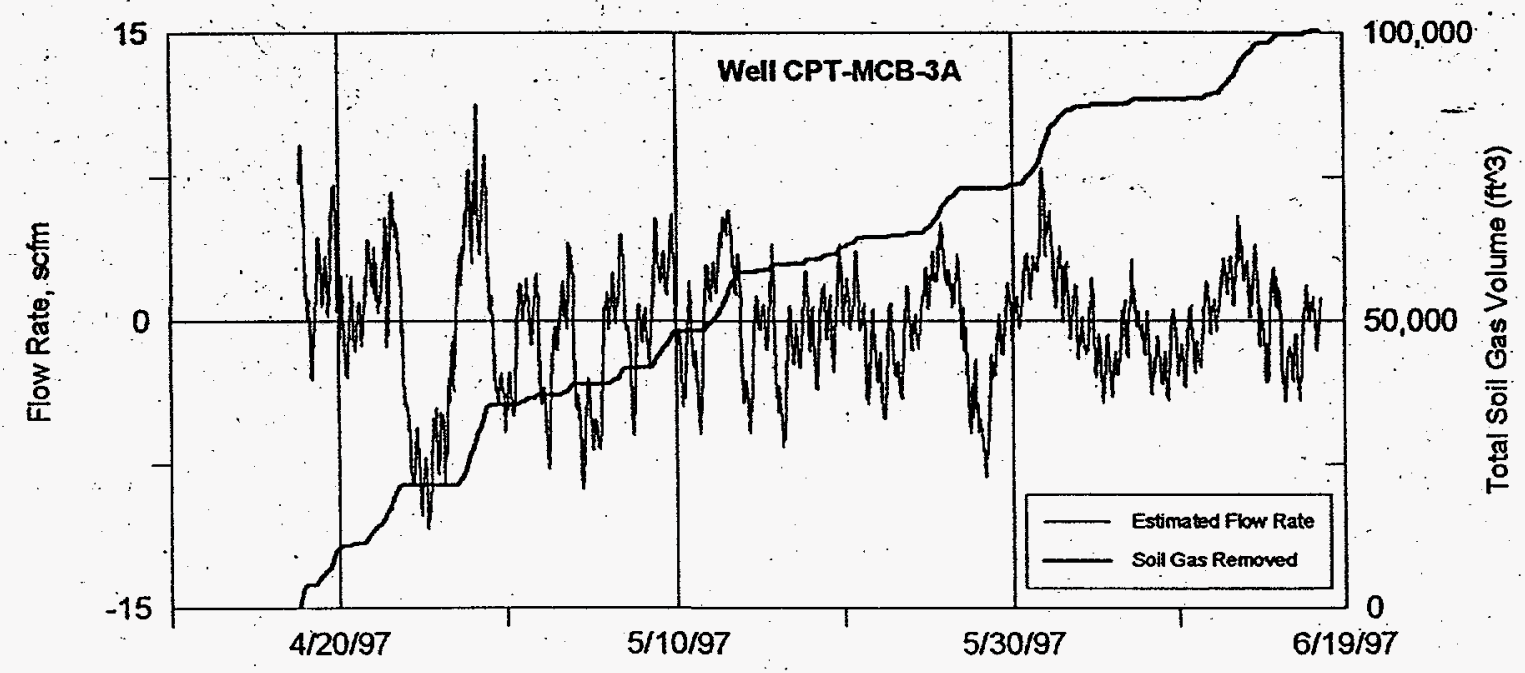

Figure 3 - Estimated Flow Rate and Volume Removed with Flow Enhancement 
Table 1 - Statistics from Pressure and Flow Measurements at CPT-MCB-3A

\begin{tabular}{|l|l|}
\hline Duration 4/17/97-6/17/97 & 61 days \\
\hline Barometric Pressure Range & 983.8 to $1015.3 \mathrm{mbar}$ \\
\hline Differential Pressure Range & -3.24 to +3.39 in $\mathrm{H}_{2} \mathrm{O}:$ \\
\hline Outflow Events & 30.4 days $(49.8 \%)$ \\
\hline Total Outflow & $100,356 \mathrm{ft} 3$ \\
\hline Total Inflow (if Baroball not installed) & $125,717 \mathrm{ft3}$ \\
\hline Average Outflow & $2.28 \mathrm{cfm}$ \\
\hline Average Outflow Event Duration & 0.50 days \\
\hline Maximum Outflow Event Duration & 3.36 days \\
\hline
\end{tabular}

Well vapor concentrations were measured approximately monthly to determine the soil gas concentration trends at the MCB. Well head measurements were made during outflow events with a Bruel and Kjaer infrared photo-acoustic analyzer calibrated for PCE; TCE, $\mathrm{CCl}_{4}$, and $\mathrm{CO}_{2}$. The contaminant concentrations were normalized with the $\mathrm{CO}_{2}$ concentrations to the average soil gas $\mathrm{CO}_{2}$ levels of $12,000 \mathrm{ppmv}$. This normalization was required to provide more accurate contaminant concentration levels at the unit. The Baroballs leak slightly during inflow periods which dilutes the soil gas and produces low readings during the beginning of outflow events. The normalized concentration values are provided in Appendix A.

Soil gas concentrations measured over this 1.1 year time period show an exponentially declining concentration as is expected based on a conceptual model of mass transfer from fine grain zones in the liquid or aqueous phase to the coarse grain sediments in the gas phase. Once in the gas phase, the contaminants can be swept out of the subsurface system. The rate constants calculated from these plots show that the wells outside of the source zone will be below 1 ppmv in approximately three years simply using PSVE. The source zone wells will be below 1 ppmv in approximately 10 years using no additional remediation method. The parameters for the exponential concentration decline equations are provided in Table 6. Concentration trends from four wells along with the exponential fits are shown in Figure 4 as an example. 


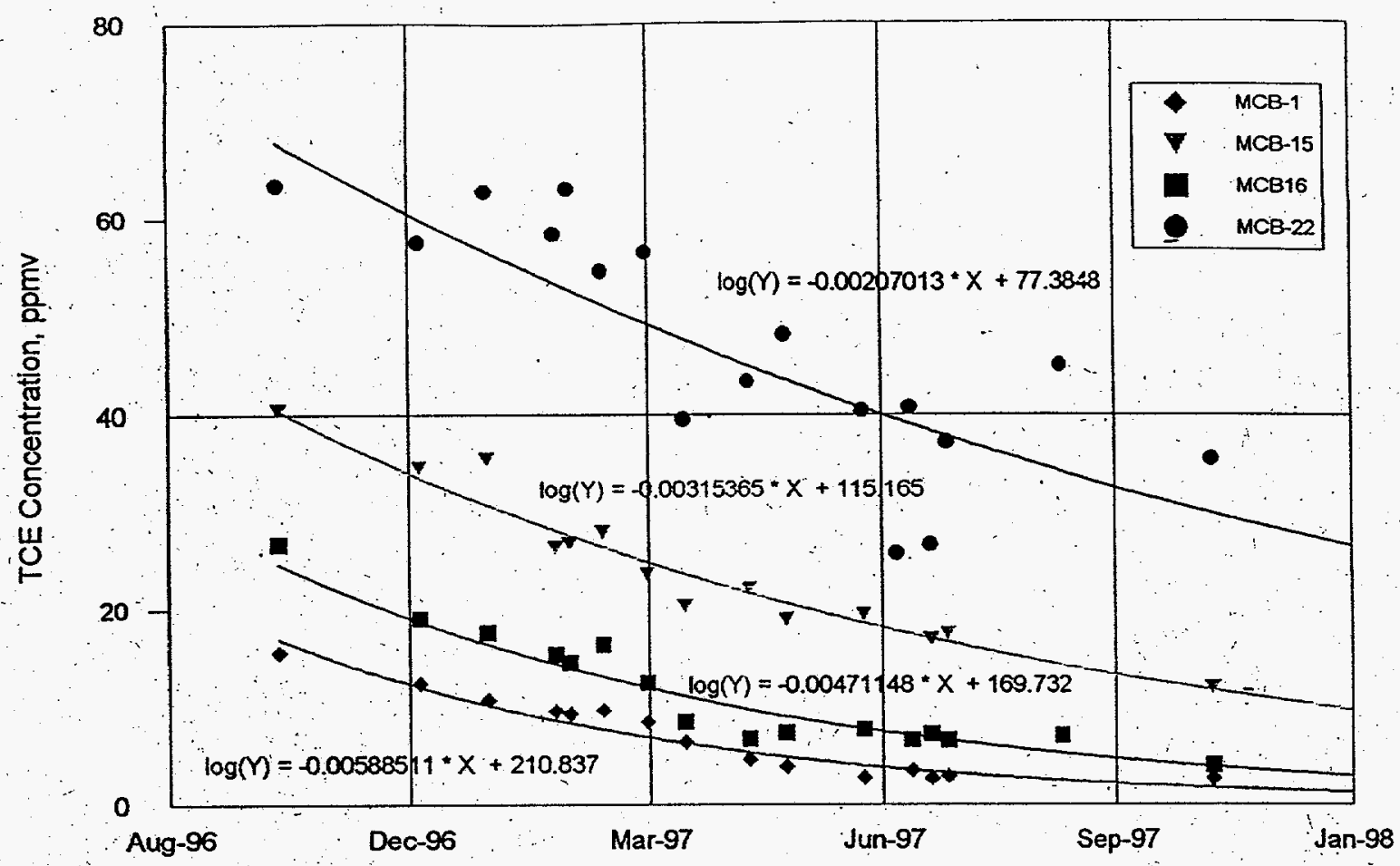

Figure 4 - Well Vapor Concentration Trends and Exponential Fits

Contour plots of well TCE concentrations at 10/7/96 and 11/7/97 are provided in Figure 5 The 25 wells are screened at different levels so these plots show a general representation of the soil gas plume at the unit Over the 13 months of PSVE with Baroball flow enhancement, the soil gas plume has decreased in concentration and size. The plume suggests that the source term is isolated around CPT-MCB-4. 

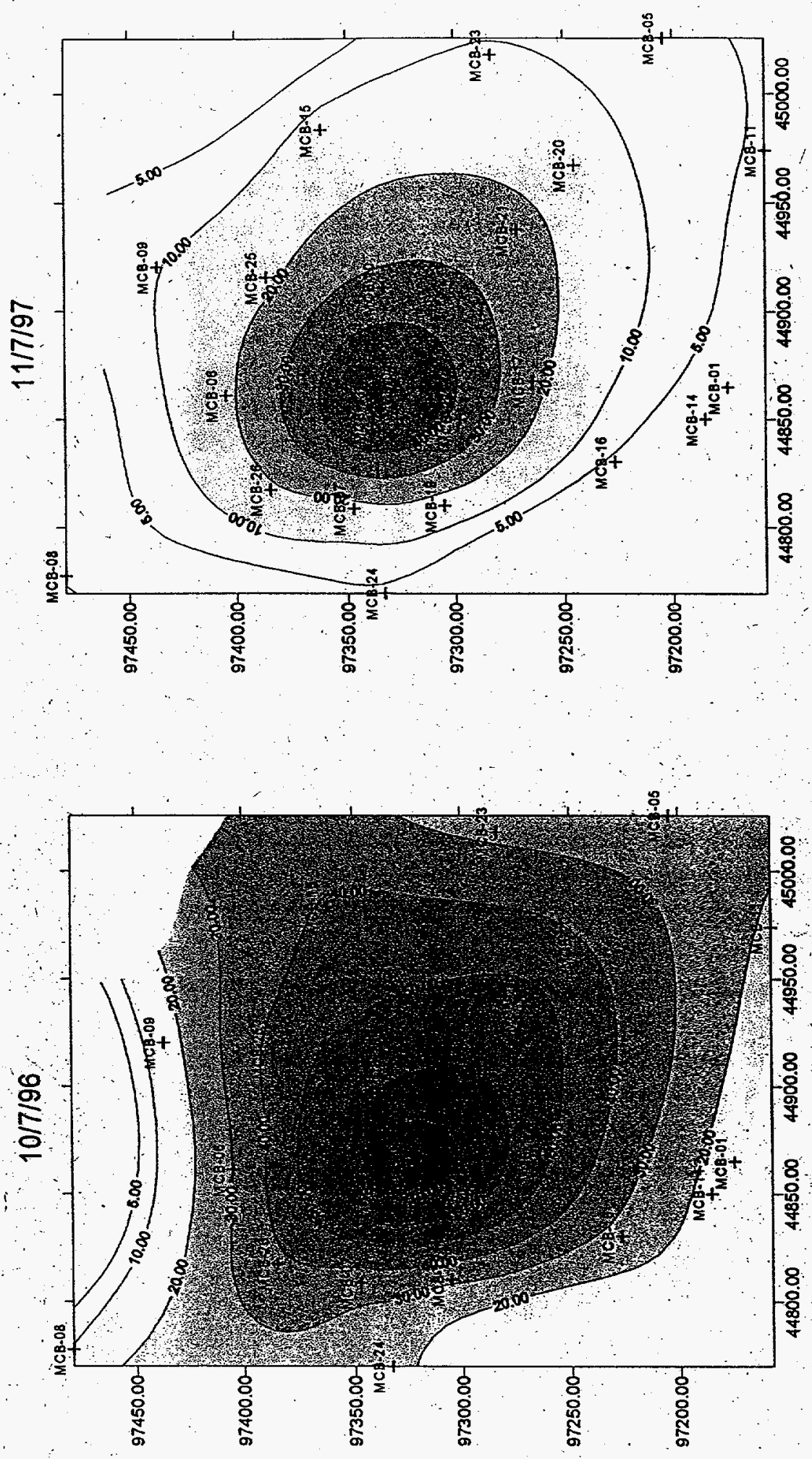

Figure 5 - Pre and Post-Study Soil Gas Plumes 


\section{Pre and Post Study Sediment Concentration}

Post-study sediment samples were collected at 5 locations within $3 \mathrm{ft}$ of the pre-study CPT sediment sample locations. Pre-study samples were collected September 1996 and post study samples were collected November 1997 . The depths of samples targeted fine grain zones and depths with detectable contaminant levels from the original sampling. The methods for sampling and analysis are discussed in the methods section above. The poststudy sediment samples were all taken within the fine grain zones.(low permeability zones).

Pre and post-study TCE concentration plots are shown in Figure 6 and 7 and the data are presented in Table 2. The locations correspond to the soil boring locations in Figure 1. The pre and post-study concentrations vary significantly; some locations show an increase and some a decrease. Observed decreases during the short treatability study were expected to be small, especially from the fine grained sediments, due to mass transfer limitations. Differences between the pre and post-study concentrations may be attributed to PSVE impacts and several other factors including the heterogeneous disposition of the contaminants corresponding to sediment properties, migration of the sorbed contaminants and the difficulty in obtaining soil samples from identical locations in the interbedded geology. Quality checks on the field and laboratory work indicate the pre and post-test data sets are equivalent.in terms of sampling and analysis.

Despite the short operating period and observed variability, the composite results from the sediment sampling suggest a $13 \%$ decrease in TCE mass from the fine grain sediments in the source area of the unit during 13 months of PSVE. This value was calculated using the difference in estimated total contaminant mass from pre- and post-study core samples. Although supported by the observation of diminished soil gas concentration, the sediment values may not be precisely representative of the true remediation rate because of the inherent variability in point sampling and the heterogeneity of contaminant distribution.

Mass removal during this time frame is primarily attributed to residual contamination in the coarse grained material and contaminant mass transfer from the finer grained zones to coarse zones where the majority of the PSVE flow is achieved. Removal from the fine grained sediments will be limited by the mass transfer from these zones to the coarse grained zones. 

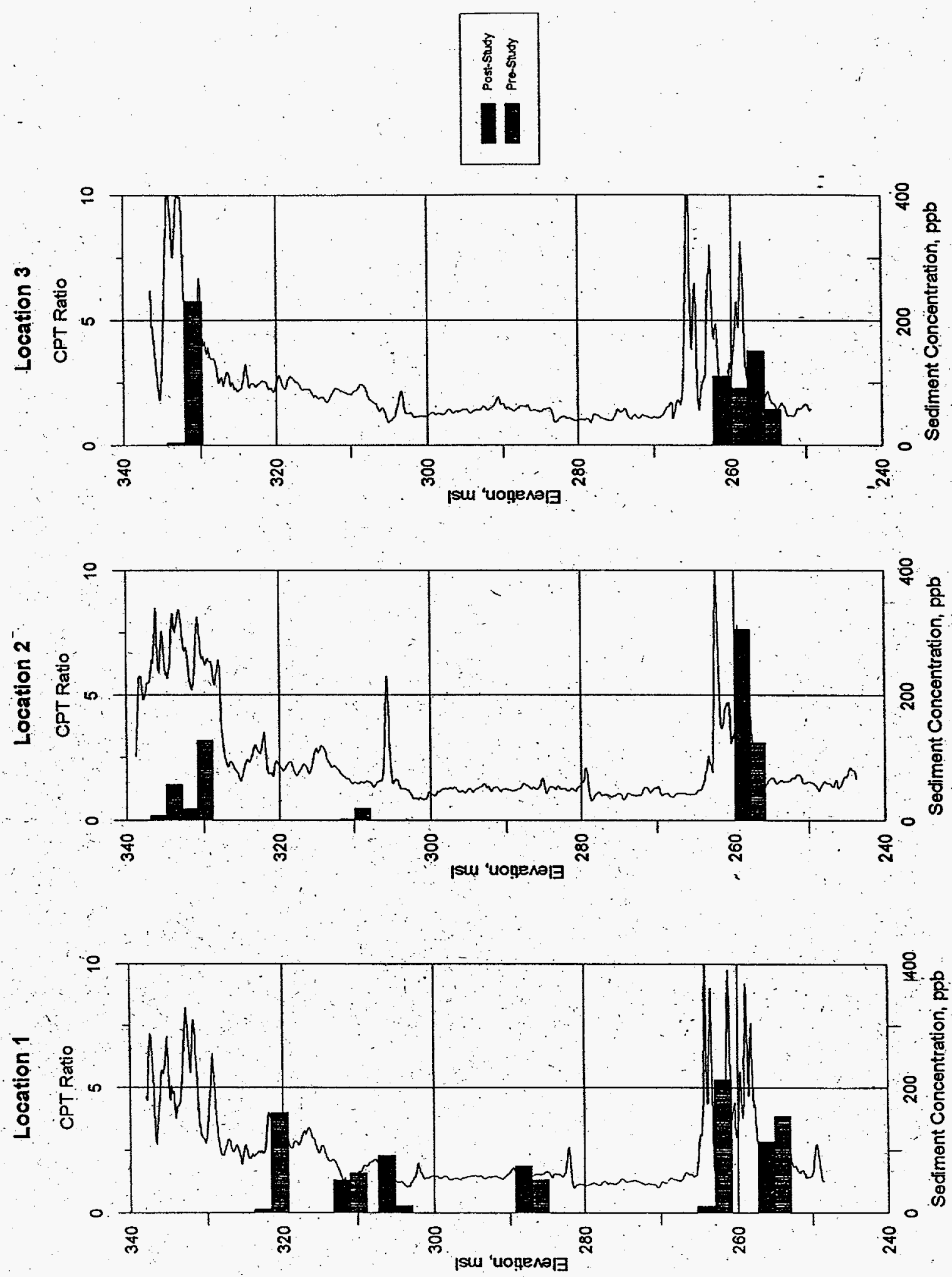

Figure 6 - Pre and Post-Study TCE Sediment Concentration Profiles (Locations 1-3) 

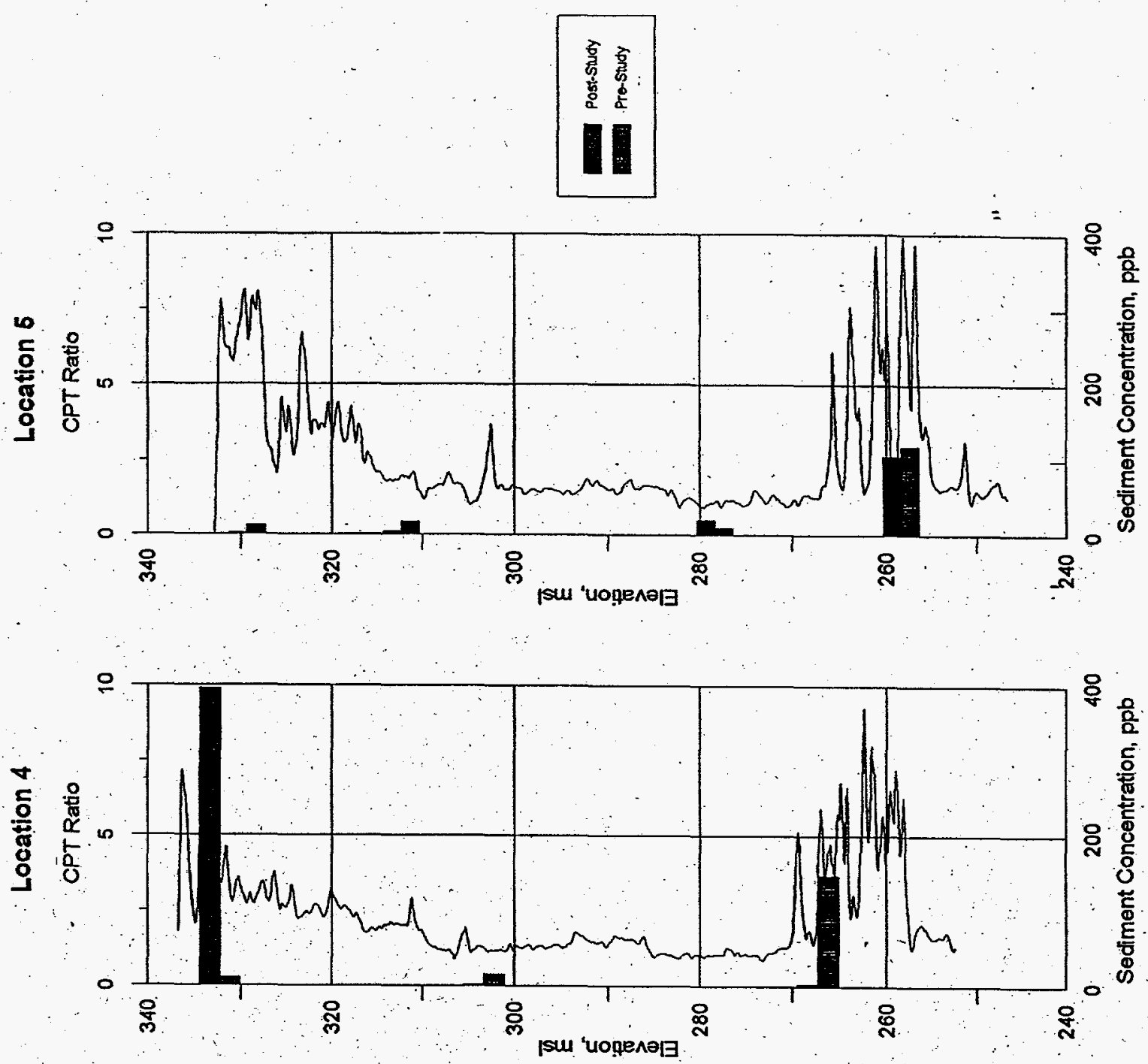

Figure 7 - Pre and Post-Study TCE Sediment Concentration Profiles (Locations 4-5) - 
Table 2- Pre and Post Study Sediment Concentrations ( $\mu \mathrm{g} / \mathrm{kg})$

\begin{tabular}{|c|c|c|c|c|c|c|c|}
\hline Location & Depth, ft & pre-CCl4 & post-CC14 & pre-TCE & post-TCE & pre-PCE & post-PCE \\
\hline S1 & 16 & $<6.6$ & $<6.6$ & 159.98 & $<6.6$ & 39.87 & $<6.6$ \\
\hline S1 & 26 & $<6.6$ & $<6.6$ & 63.97 & 52.37 & 9.94 & 8.16 \\
\hline S1 & 32 & $<6.6$ & $<6.6$ & 11.19 & 92.65 & $<6.6$ & -8.61 \\
\hline S1 & 50 & $<6.6$ & $<6.6$ & 52.42 & 74.46 & 8.76 & 8.51 \\
\hline S1 & 74 & $<6.6$ & $<6.6$ & 213.16 & 10.62 & 35.87 & $<6.6$ \\
\hline S1 & 82 & $<6.6$ & $<6.6$ & 154.66 & 114.03 & 18.70 & 11.98 \\
\hline S2 & 4 & 10.86 & $<6.6$ & 56.53 & 6.96 & 6023.62 & $<6.6$ \\
\hline S2 & 8 & 6.82 & $<6.6$ & 126.25 & 17.06 & 231.42 & $<6.6$ \\
\hline S2 & 29 & $<6.6$ & $<6.6$ & 18.53 & $<6.6$ & 10.29 & $<6.6$ \\
\hline S2 & 81 & $<6.6$ & 10.96 & 123.11 & 305.06 & 33.03 & 114.87 \\
\hline S3 & 4 & $<6.6$ & $<6.6$ & 229.86 & $<6.6$ & 25.17 & $<6.6$ \\
\hline S3 & 75 & $<6.6$ & $<6.6$ & 90.86 & 110.01 & 14.94 & 19.47 \\
\hline S3 & 80 & $<6.6$ & $<6.6$ & 57.13 & 150.78 & 8.72 & 24.94 \\
\hline S4 & 4 & $<6.6$ & $<6.6$ & 9.80 & 395.17 & $<6.6$ & 15.77 \\
\hline S4 & 33 & $<6.6$ & $<6.6$ & 14.75 & $<6.6$ & $<6.6$ & $<6.6$ \\
\hline S4 & 69 & 24.70 & $<6.6$ & 146.51 & $<6.6$ & 5324.95 & $<6.6$ \\
\hline S5 & 4 & $<6.6$ & $<6.6$ & 12.14 & $<6.6$ & $<6.6$ & $<6.6$ \\
\hline S5 & 21 & $<6.6$ & $<6.6$ & 17.15 & $<6.6$ & $<6.6$ & $<6.6$ \\
\hline S5 & 55 & $<6.6$ & $<6.6$ & 9.32 & 19.76 & $<6.6$ & $<6.6$ \\
\hline S5 & 74 & $<6.6$ & $<6.6$ & 118.14 & 105.52 & 13.73 & 8.33 \\
\hline
\end{tabular}

\section{Flow Control Enhancement of Mass Removal}

Flow control enhancement has been proven to increase mass removal by at least a factor of 2 (May et al., 1994). Theoretically, without any engineering controls, the volume of soil gas outflow is approximately equal to the volume inflow in an open vadose zone well. Under these conditions, air entering the vadose zone will dilute the soil gas and force the soil gas plume away from the well. The soil gas removed after an inflow event will thus be a mixture of surface air and soil gas, effectively reducing the mass of contaminants removed.

With flow control which only allows outflow, the soil gas is not diluted and a step process is created which brings contaminants from further distances from the well screen with each successive outflow event. Also, when wells are not flowing out (checked inflow event), contaminants will move into the coarse grained sediments by mass transfer and will be removed during the next outflow event(s). The Baroball check valve does leak slightly during inflow events and will produce some subsurface dilution dependent on the length of the inflow event.

\section{Solar Heat Enhancement of Mass Removal}

PSVE has been successfully removing chlorinated organic contaminants from the vadose zone at the Miscellaneous Chemical Basin for more than one year. This process has been steady but slow (approximately $100 \mathrm{lbs}$. of chlorinated solvents in the first year). The rate of removal is dependent on both the rate of PSVE (i.e., the gas flow rate out of the wells) and 
the mass transfer rate of the contaminants from within the fine grain zones to the coarse grain zones. The majority of the advective flow of PSVE occurs in the coarse grain zones (i.e., zones of higher permeability) in the vadose zone. An active vapor extraction system (e.g., vacuum blower) can increase the flow rate out of the wells and the contaminant removal rate. This strategy is effective until the contaminant mass transfer limitations are dominant. At this point, the active vapor extraction reaches a point of diminishing returns in its removal effectiveness. Once installed, a PSVE system never reaches a removal effectiveness point of diminishing returns because it has a negligible operation and maintenance cost.

An alternative method to increase contaminant removal rate is by increasing the mass transfer processes in the system. Heating the subsurface system is an effective way to accomplish this. Heating exploits the physical properties of the volatile contaminants by increasing the vapor pressure of the contaminant in the system. For PCE and TCE, a temperature rise of $10^{\circ} \mathrm{C}$ results in a nearly two fold increase of the vapor pressure. By. doubling the vapor pressure, twice the mass of contaminants will be in the vapor phase and available for removal by soil vapor extraction. Increased temperature also increases diffusion coefficients and related mass transfer processes. Using a set of simple assumptions we can approximate the energy required for a temperature increase of $10^{\circ} \mathrm{C}$ in the subsurface system a priori. Table 3 below lists the assumptions and energy calculations.

Table 3 - Energy Required for Heating Subsurface in PSVE Volume of Influence

\begin{tabular}{|l|l|l|l|}
\hline Radius of Influence & $3 \mathrm{~m}$ & \\
\hline Well Screen Length & $2 \mathrm{~m}$ & Volume of Influence & $56.5 \mathrm{~m}^{3}$ \\
\hline Porosity & 0.4 & & \\
\hline Volumetric soil moisture $\left(\mathrm{S}_{\mathrm{w}}\right)$ & 0.6 & & \\
\hline Sediment Density & $2,650 \mathrm{~kg} / \mathrm{m}^{3}$ & Mass of Sediments & $89,912 \mathrm{~kg}$ \\
\hline Water Density & $1,000 \mathrm{~kg} / \mathrm{m}^{3}$ & Mass of Water & $13,572 \mathrm{~kg}$ \\
\hline Sediment heat capacity $\left(\mathrm{C}_{\mathrm{vs}}\right)$ & $0.79 \mathrm{BTU} / \mathrm{kg} / \mathrm{C}$ & Energy for $10^{\circ} \mathrm{C}$ rise (sediments) & $713,602 \mathrm{BTU}$ \\
\hline Water heat capacity $\left(\mathrm{C}_{\mathrm{vw}}\right)$ & $3.97 \mathrm{BTU} / \mathrm{kg} / \mathrm{C}$ & Energy for $10^{\circ} \mathrm{C}$ rise (water) & $538,568 \mathrm{BTU}-$ \\
\hline & & Total Energy Required. & $1,252,170 \mathrm{BTU}$ \\
\hline
\end{tabular}

Given this energy target, cost-effective strategies can be selected to heat the subsurface and double the contaminant removal rate.

In the southeastern United States, solar energy can be used to create a large amount of heat cost-effectively. By using innovative passive solar collection devices developed as a result of a SRS Cooperative Research and Development Agreement (CRADA) with a local company, it has been demonstrated that solar energy can be efficiently converted to heat energy to warm surface sediments near the M Area Basin. By joining the two passive technologies (passive solar collector and passive soil vapor extraction/injection) it should be possible to heat the subsurface using only natural energy sources. Data were collected on available solar 
energy at SRS using a pyrometer and data logger as part of the CRADA. The data are summarized in Table 4 below and compared to theoretical solar energy availability.

Table 4 - Energy Available from the Sun at SRS

\begin{tabular}{|l|l|l|l|}
\hline Average sun/day & 6 hours & Area of collector & $5.9 \mathrm{~m}^{2}$ \\
\hline Theoretical & & Measured & \\
\hline Average Energy from Sun (approx.) & $0.95 \mathrm{BTU} / \mathrm{sec} / \mathrm{m}^{2}$ & Áverage Energy from Sun & $0.70 \mathrm{BTU} / \mathrm{sec} / \mathrm{m}^{2}$ \\
\hline Energy to collector & $121,734 \mathrm{BTU} / \mathrm{day}$ & Energy to collector & $89,600 \mathrm{BTU} / \mathrm{day}$ \\
\hline
\end{tabular}

Using the measured value of energy available at SRS and assuming $100 \%$ efficiency of solar energy collection and complete transfer of that energy to the subsurface, a $10^{\circ} \mathrm{C}$ rise in temperature can be achieved in 14 days.

Passive subsurface injection is the transmission of surface air into the subsurface using the same pressure gradients that enabled passive soil vapor extraction, only in this instance, surface pressure is higher than subsurface pressure. Air is not an efficient heat transfer fluid so to transfer heat developed in the solar collector air saturated with water (i.e., steam) would be used. The steam will condense on contact with the lower temperature sediments, which are at a nominal temperature of $19^{\circ} \mathrm{C}$. The low temperature steam injection is an effective method for rapidly transferring energy because the latent energy of the steam is immediately transferred to the subsurface sediments when the steam condenses. To create the watersaturated air, we maintain a reservoir of water in the sealed solar collector and allow surface air in through baffles only when steam injection is occurring. In Table 5 below, the physical parameters of the passive solar collector and estimated heat capacity and flux are provided for creating and transferring steam at different temperatures. A time history of the temperature in the solar heat collector is shown in Figure 8.

Table 5 - Passive Steam Injection Rates

\begin{tabular}{|c|c|c|}
\hline Temperature $\left({ }^{\circ} \mathrm{C}\right)$ & Approximate BTU/day & Number of days to raise sediments $10^{\circ} \mathrm{C}$ \\
\hline 130 & 74810 & 17 \\
\hline 120 & 57600 & 22 \\
\hline 110 & 40000 & 31 \\
\hline 100 & 26830 & 47 \\
\hline 80 & 14740 & 85 \\
\hline 60 & 5790 & 216 \\
\hline 40 & 2020 & 618 \\
\hline
\end{tabular}

From the table above it is clear that the higher the temperatures achieved, the more effective the heat transfer. An added benefit of higher temperature steam not accounted for above is the increase in pressure created in the solar collector and subsequent increase potential flow to the subsurface. The increase in pressure also may create difficulties in maintaining the airtight seal in the solar collector. The experiments scheduled for this fiscal year should provide the performance parameters for this system. 


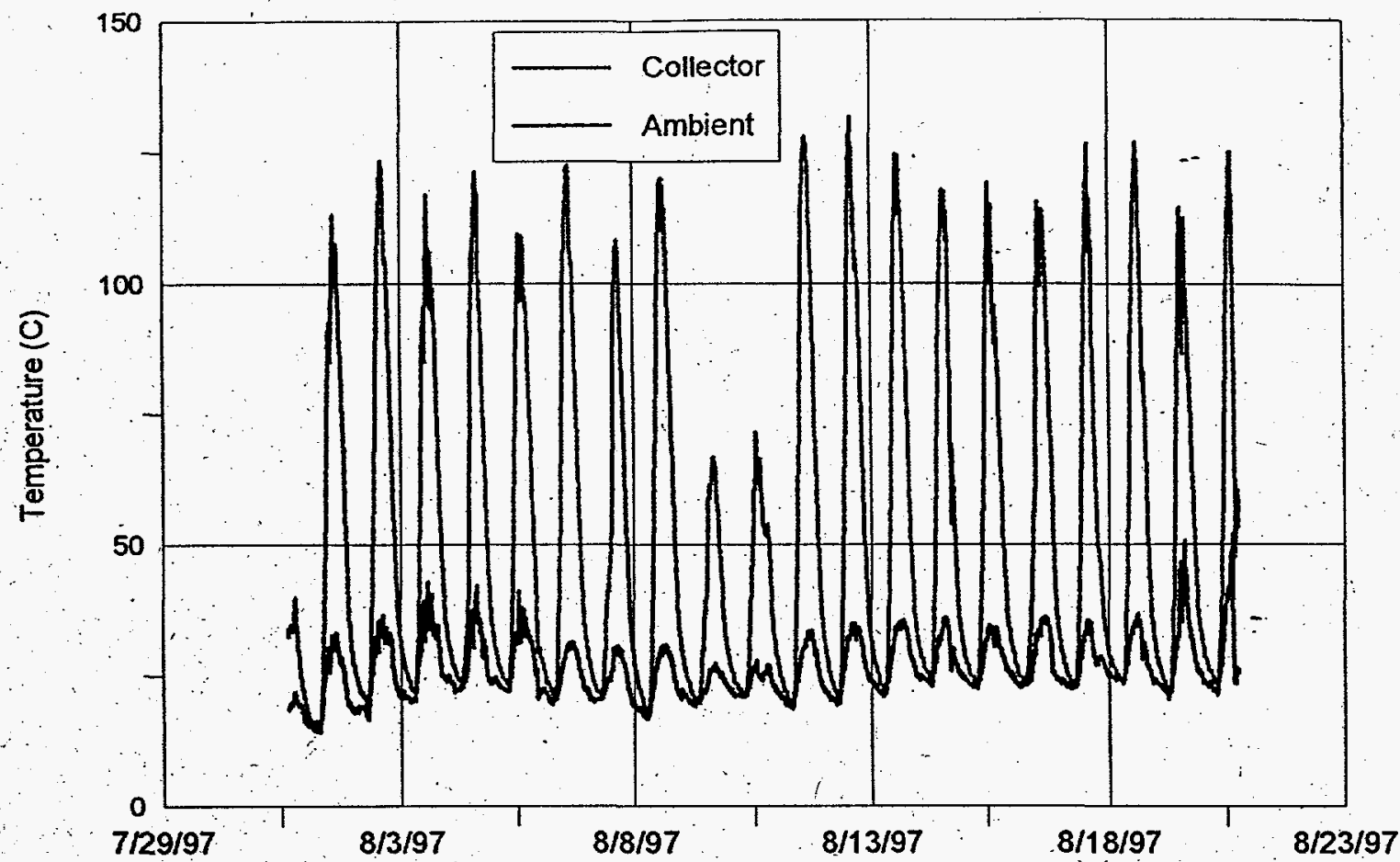

Figure 8 - Time History of Solar Heat Collector Temperatures

\section{Cost Analysis}

Based on the exponentially declining concentration curves for 19 of the wells installed at the Miscellaneous Chemical Basin, life-cycle costs can be developed for removal of the chlorinated contaminants using a PSVE system. The assumptions include a uniform average flow rate out of all of the wells based on measured flow from the wells, initial concentrations measured 10/7/96 and final concentration projected using the rate constants from more than a year of monitoring.

O'perating and maintenance costs are assumed negligible for this cost analysis so that the total cost of the project was incurred during installation in the summer of 1996. Costs are calculated in terms of dollars per pound of contaminant removal in 1996 dollars. The installation cost includes the entire cost of the cone penetrometer characterization and 25 well installations performed in three weeks during August, 1996. In general, characterization costs should not be included in remediation system cost analyses. Without concurrent characterization, the costs will be lower.

The cost per pound of removal is calculated for two average flow rates ( $2 \mathrm{scfm}$ and $4 \mathrm{scfm}$ ). Soil gas is removed $50 \%$ of the time (50\% of the time atmospheric air is blowing into well). The area under the removal curves is calculated and multiplied by the flow rate to obtain the mass of contaminant removed. The total mass removed at the Miscellaneous Chemical Basin 
for a given time period is the sum of the mass removed from the individual wells. The cost of installation is then divided by the mass removed resulting in the cost per pound of contaminant removed. The cost per pound of removal is quoted for two time periods (and two flow rates): cost per pound for 1.1 year, and cost per pound for 10 years. The calculations show that contaminant concentrations in all wells will be approximately 1 ppmy within 10 years. The calculated mass removal and costs are presented in Tables 6 and 7. Cost estimates for a solar heat enhanced system will be developed after tests are concluded in FY98.

Table 6 - Mass Removed by PSVE from 10/7/96 to 11/7/97 and Projected Mass Removed in 10 Years

\begin{tabular}{|c|c|c|c|c|c|c|c|c|c|}
\hline \multirow{3}{*}{$\begin{array}{l}\text { Well \# } \\
\text { MCB- }\end{array}$} & \multirow{2}{*}{\multicolumn{2}{|c|}{$\begin{array}{c}\text { TCE } \\
\text { Concentration Decay } \\
\text { Constants }\end{array}$}} & \multirow{2}{*}{\multicolumn{3}{|c|}{ TCE Conc (ppmv)@ date: }} & \multicolumn{4}{|c|}{ Mass (kg) Removed by date } \\
\hline & & & & & & \multicolumn{2}{|c|}{$\begin{array}{c}\text { November 7, } 1997 \\
\text { For Avg. Flow Rate: }\end{array}$} & \multicolumn{2}{|c|}{$\begin{array}{c}\text { October 7,2006 } \\
\text { For Avg. Flow Rate: }\end{array}$} \\
\hline & . $\mathbf{A}$ & $\bar{B}$ & $10 / 7 / 96$ & $11 / 7 / 97$ & $10 / 7 / 06$ & $2,00 \mathrm{scfm}$ & $4.00 \mathrm{scfm}$ & $2.00 \mathrm{scfm}$ & $4.00 \mathrm{scfm}$ \\
\hline 13 & $1.00 \mathrm{E}+20$ & $-0,0012$ & 38.00 & 23.63 & 0.47 & $2.67 \mathrm{~kg}$ & $5.34 \mathrm{~kg}$ & $6.97 \mathrm{~kg}$ & $.13 .94 \mathrm{~kg}$ \\
\hline 10 & $1.00 \mathrm{E}+23$ & -0.0014 & 32.34 & 18.58 & 0.19 & $2.19 \mathrm{~kg}$ & $4.38 \mathrm{~kg}$ & $5.12 \mathrm{~kg}$ & $10.23 \mathrm{~kg}$ \\
\hline 9 & $3.00 \mathrm{E}+40$ & -0.0025 & 126.41 & 46.97 & 0.01 & $7.08 \mathrm{~kg}$ & $14.16 \mathrm{~kg}$ & $11.27 \mathrm{~kg}$ & $22.53 \mathrm{~kg}$ \\
\hline 11 & $2.00 \mathrm{E}+62$ & -0.004 & 7.95 & 1.63 & 0.00 & $0.35 \mathrm{~kg}$ & $0.70 \mathrm{~kg}$ & $0.44 \mathrm{~kg}$ & $0.89 \mathrm{~kg}$ \\
\hline 8 & $3.00 \mathrm{E}+28$ & -0.0018 & 7.03 & 3.45 & 0.01 & $0.44 \mathrm{~kg}$ & $0.89 \mathrm{~kg}$ & $0.87 \mathrm{~kg}$ & $1.74 \mathrm{~kg}$ \\
\hline 4 & $2.00 \mathrm{E}+21$ & -0.0013 & 22.17 & 13.25 & 0.19 & $1.53 \mathrm{~kg}$ & $3.06 \mathrm{~kg}$ & $3.77 \mathrm{~kg}$ & $7.54 \mathrm{~kg}$ \\
\hline 7 & $9.00 \mathrm{E}+49$ & -0.0031 & 233.78 & 68.50 & 0.00 & $11.88 \mathrm{~kg}$ & $23.76 \mathrm{~kg}$ & $16.81 \mathrm{~kg}$ & $33.61 \mathrm{~kg}$ \\
\hline$\overline{6}$ & $4.00 \mathrm{E}+44$ & -0.0028 & 41.85 & 13.81 & 0.00 & $2.23 \mathrm{~kg}$ & $4.46 \mathrm{~kg}$ & $3.33 \mathrm{~kg}$ & $6.66 \mathrm{~kg}$ \\
\hline 1 & $4.00 \mathrm{E}+91$ & -0.0059 & 10.87 & 1.05 & 0.00 & $0.37 \mathrm{~kg}$ & $0.74 \mathrm{~kg}$ & $0.41 \mathrm{~kg}$ & $0.82 \mathrm{~kg}$ \\
\hline 5 & $1.00 \mathrm{E}+58$ & -0.0037 & 16.01 & 3.70 & 0.00 & $0.74 \mathrm{~kg}$ & $1.48 \mathrm{~kg}$ & $0.96 \mathrm{~kg}$ & $1.93 \mathrm{~kg}$ \\
\hline 17 & $3.00 \mathrm{E}+44$ & -0.0028 & 31.39 & 10.36 & 0.00 & $1.67 \mathrm{~kg}$ & $3.35 \mathrm{~kg}$ & $2,50 \mathrm{~kg}$ & $5.00 \mathrm{~kg}$ \\
\hline 15 & $1.00 \mathrm{E}+50$ & -0.0032 & 7.58 & $\therefore 2.13$ & $0: 00$ & $0.38 \mathrm{~kg}$ & $0.76 \mathrm{~kg}$ & $0.53 \mathrm{~kg}$ & $1,06 \mathrm{~kg}$ \\
\hline 16 & $5.00 \mathrm{E}+73$ & -0.0047 & 35.75 & 5.56 & 0.00 & $1.43 \mathrm{~kg}$ & $2.86 \mathrm{~kg}$ & $1.70 \mathrm{~kg}$ & $3.39 \mathrm{~kg}$ \\
\hline 14 & $5.00 \mathrm{E}+86$ & -0.0056 & 5.47 & 0.60 & 0.00 & $0.19 \mathrm{~kg}$ & $0.39 \mathrm{~kg}$ & $0.22 \mathrm{~kg}$ & $0.44 \mathrm{~kg}$ \\
\hline 22 & $4.00 \mathrm{E}+33$ & -0.0021 & 23.27 & 10.13 & 0.01 & $1.39 \mathrm{~kg}$ & $2.79 \mathrm{~kg}$ & $2.47 \mathrm{~kg}$ & $4.94 \mathrm{~kg}$ \\
\hline 26 & $2.00 \mathrm{E}+22$ & $-0: 0014$ & 6.47 & 3.72 & 0.04 & $0.44 \mathrm{~kg}$ & $0.88 \mathrm{~kg}$ & $1.02 \mathrm{~kg}$ & $2.05 \mathrm{~kg}$ \\
\hline 24 & $4.00 \mathrm{E}+74$ & -0.0048 & 8.34 & 1.25 & 0.00 & $0.33 \mathrm{~kg}$ & $0.66 \mathrm{~kg}$ & $0.39 \mathrm{~kg}$ & $0.77 \mathrm{~kg}$ \\
\hline 25 & $4.00 \mathrm{E}+33$ & -0.0021 & 23.27 & 10.13 & 0.01 & $1.39 \mathrm{~kg}$ & $2.79 \mathrm{~kg}$ & $2.47 \mathrm{~kg}$ & $4.94 \mathrm{~kg}$ \\
\hline 23 & $9.00 \mathrm{E}+42$ & -0.0027 & 32.28 & 11.08 & 0.00 & $1.75 \mathrm{~kg}$ & $3.50 \mathrm{~kg}$ & $2.66 \cdot \mathrm{kg}$ & $.5 .33 \mathrm{~kg}$ \\
\hline
\end{tabular}

Conc $=\mathrm{Ae}^{(\mathrm{Bt})}$. Assumes average flow rate when wells are blowing. Wells blowing out $50 \%$ of time

Table 7 - Total TCE Mass Removed and Estimated Cost for Removal

\begin{tabular}{|l|c|c|c|c|}
\hline & \multicolumn{2}{|c|}{ After 1.1 years } & \multicolumn{2}{c|}{ After 10 years } \\
\hline Flow Rate & $2 \mathrm{scfm}$ & $4 \mathrm{scfm}$ & $2 \mathrm{scfm}$ & $4 \mathrm{scfm}$ \\
\hline Total Mass Removed & $38.48 \mathrm{~kg}$ & $76.94 \mathrm{~kg}$ & $63.9 \mathrm{~kg}$ & $127.8 \mathrm{~kg}$ \\
\hline Removal Cost & $\$ 1,559 / \mathrm{kg}$ & $\$ 780 / \mathrm{kg}$ & $\$ 939 / \mathrm{kg}$ & $\$ 470 / \mathrm{kg}$ \\
\hline & $\$ 709 / \mathrm{lb}$ & $\$ 354 / \mathrm{lb}$ & $\$ 427 / \mathrm{lb}$ & $\$ 213 / \mathrm{lb}$ \\
\hline
\end{tabular}

Installation Cost $=\$ 60,000$ 


\section{Conclusions}

The results to date on the treatability study of the PSVE system at the Miscellaneous Chemical Basin of the Savannah River Site indicate that the technology is performing well. In just over one year more than 100 pounds of chlorinated organic contaminants have been removed by natural barometric pumping of wells fitted with BaroBall valves (low pressure check valves). Contour maps of the vadose zone contaminant gas plume made before the study and after 1.1. years show a significant decrease in the extent of the soil gas plume and identify the source location. From extrapolations of the exponentially declining contaminant concentrations measured in the wells, all of the wells except those in the source zone are estimated to be below $1 \mathrm{ppmv}$ in approximately three years simply using PSVE. The source zone wells are estimated to be below 1 ppmv in approximately 10 years using no additional remediation method.

Mass removal during this time frame is primarily attributed to residual contamination in the coarse grained material and some contaminant mass transfer from the finer grained zones to coarse zones where the majority of the PSVE flow is achieved. Removal from the fine grained sediments will be limited by the mass transfer from these zones to the coarse grained zones.

The PSVE system has required minimal operating and maintenance costs and can be expected to operate continuously for at least 10 years with no intervention. The cost for the initial installation of the system (including continuous geologic and chemical characterization, and the installation of 25 wells with screens lengths and positions selected based on depth-discrete soil gas analyses all performed in three weeks) was approximately $\$ 60 \mathrm{~K}$.

To remediate the source zones more quickly, passive heat injection is proposed as an extension to the treatability study. From previous testing and theoretical calculations, the subsurface can be heated using a passive solar collector and passive soil vapor injection. If the subsurface temperature can be raised by $10 \mathrm{C}$, contaminant removal rate can be doubled.

All of the vadose zone extraction wells installed can also be used with an active vapor extraction system. This system would be most useful on wells near the source zone. An active extraction system will remove contaminants much faster than a PSVE system. An evaluation of the cost for installing and operating the active system should be compared with the current status quo (i.e., PSVE alone).

The PSVE system is performing well in a cost-effective manner. It is recommended that this system be allowed to continue operating for at least another year to verify the anticipated contaminant removal rates and to further evaluate removal effectiveness in the lower permeability zones. 


\section{References}

May, C.P., B.D. Riha, J. Rossabi, B.E. Pemberton; B.B. Looney. 1994. The Influence of Atmospheric Pressure Fluctuations on Soil Gas Sampling. Eos Transactions, American Geophysical Union 1994 Fall Meeting.

Riha, B.D., B.E. Pemberton, and J. Rossabi. 1996. "Miscellaneous Chemical Basin Expedited Site Characterization Report (U)". WSRC-TR-96-0407. Westinghouse Savannah River Company, Aiken, SC. 


\section{APPENDIX A - Well Vapor Concentrations}




\begin{tabular}{|c|c|c|c|c|c|c|c|c|c|c|c|c|}
\hline \multirow[b]{2}{*}{ Date } & \multicolumn{3}{|l|}{ MCB-1 } & \multicolumn{3}{|l|}{$\overline{M C B-4}$} & \multicolumn{3}{|l|}{ MCB-5 } & \multicolumn{3}{|l|}{ MCB-6 } \\
\hline & PCE & TCE & $\mathrm{CO} 2$ & PCE & TCE & $\mathrm{CO} 2$ & PCE & TCE & $\mathrm{CO} 2$ & PCE & TCE & $\mathrm{CO} 2$ \\
\hline $10 / 07 / 96$ & 1.94 & 15.53 & 10200 & 19.90 & 75.90 & 12300 & 4.29 & 22.58 & 11800 & 12.16 & 28.45 & 4640 \\
\hline $12 / 05 / 96$ & 1.32 & 12.32 & 11200 & $19: 94$ & 76.33 & 13300 & 3.32 & 19.51 & 10700 & 9.55 & 19.48 & 1860 \\
\hline $01 / 02 / 97$ & 1.53 & 10.67 & 11700 & 20.29 & 76.86 & 12600 & 3.35 & 19.20 & 11.000 & 17.11 & 36.98 & 6620 \\
\hline $01 / 30 / 97$ & 1.19 & 9.60 & 11400 & 18.12 & 75.65 & 10200 & 3.10 & 17.27 & 10700 & 14.45 & 31.01 & 3580 \\
\hline $02 / 05 / 97$ & 0.94 & 9.28 & 10800 & 17.59 & 74.78 & 9800 & 1.78 & 16.19 & 9030 & 12.33 & 30.54 & 5230 \\
\hline $02 / 19 / 97$ & 1.08 & 9.67 & 10800 & 14.65 & 69.66 & 11000 & 2.07 & 13.81 & 8620 & 10.74 & 25.16 & 3050 \\
\hline $03 / 10 / 97$ & 0.76 & 8.44 & 10900 & 17.95 & 78.61 & 10000 & 1.79 & 13.71 & 9440 & 10.56 & 25.13 & 3980 \\
\hline $03 / 26 / 97$ & 0.52 & 6.34 & 10200 & $17: 07$ & 72.94 & 9260 & 1.59 & 10.57 & 7740 & 6.56 & 14.34 & 1820 \\
\hline $04 / 23 / 97$ & 0.23 & 4.58 & 12000 & 18.38 & 75.94 & 10600 & 1.40 & 11.88 & 10900 & 8.26 & 21.96 & 7940 \\
\hline $05 / 09 / 97$ & 0.18 & 3.83 & 10600 & 17.40 & 75.33 & 10200 & 1.19 & 10.96 & 10100 & 8.83 & 22.60 & 5450 \\
\hline $06 / 11 / 97$ & 0.30 & 2.71 & 7710 & 16.38 & 68.81 & 9650 & 1.21 & 8.25 & 7930 & 5.01 & 8.96 & 2260 \\
\hline $06 / 25 / 97$ & & & & $\therefore$ & & & & & & 1.29 & 2.57 & 1810 \\
\hline $.07 / 01 / 97$ & 0.60 & 3.47 & 14000 & 17.30 & 64,65 & 12900 & 1.60 & 9.59 & 12500 & 9.05 & 20.09 & 8540 \\
\hline $07 / 09 / 97$ & 0.55 & 2.59 & 10500 & 15.98 & 60.05 & 12200 & 1.35 & 7.50 & 9530 & 6.03 & 12.71 & 4720 \\
\hline $07 / 16 / 97$ & 0.54 & 2.84 & 11600 & 16.32 & 62.78 & 12500 & 1.46 & 8.44 & 11100 & 6.21 & 11.83 & 5700 \\
\hline $09 / 03 / 97$ & & & 이 & 9.96 & 43.72 & 5110 & & & 0 & 9.56 & 23.30 & 6720 \\
\hline $11 / 07 / 97$ & 0.59 & 2.57 & 15300 & 13.94 & 51.16 & 13100 & 1.32 & 6.18 & 9920 & 7.77 & 17.00 & 9210 \\
\hline
\end{tabular}

All concentrations in ppmv and normalized by $\mathrm{CO}_{2}$ levels

MCB-2: not completed as a well

MCB-3: not measured due to low concentrations and access problems 


\begin{tabular}{|c|c|c|c|c|c|c|c|c|c|c|c|c|}
\hline \multirow[b]{2}{*}{ Date } & \multicolumn{3}{|l|}{ MCB-7 } & \multicolumn{3}{|l|}{ MCB-8 } & \multicolumn{3}{|l|}{ MCB-9 } & \multicolumn{3}{|l|}{$\longdiv { M C B - 1 0 }$} \\
\hline & PCE & TCE & CO2 & PCE & TTCE & $\mathrm{CO} 2$ & PCE & TCE & $\mathrm{CO} 2$ & PCE & TCE & $\mathrm{CO} 2$ \\
\hline $10 / 07 / 96$ & 12.04 & $\overline{34.73}$ & 6530 & 4.64 & 11.00 & 4780 & & & 0 & 13.52 & 57.38 & 6400 \\
\hline $12 / 05 / 96$ & 14.69 & 39.56 & 8250 & 4.92 & 11.27 & 7240 & 9.77 & 26.25 & 9190 & 6.91 & 32.55 & 1980 \\
\hline $01 / 02 / 97$ & 14.62 & 39.47 & 9030 & 5.87 & 10.43 & 7320 & 10.34 & 27.19 & 9400 & 12.76 & 51.65 & 4740 \\
\hline $01 / 30 / 97$ & 15.76 & 43.05 & 9060 & $2: 94$ & 7.57 & 4280 & 9.06 & 24.38 & 8910 & & & 0 \\
\hline $02 / 05 / 97$ & 12.59 & 38.40 & 8510 & 3.00 & 7.99 & 5500 & 7.82 & 22.42 & 8150 & 8.14 & 38.62 & 3460 \\
\hline $02 / 19 / 97$ & 14.85 & 42.29 & 9480 & 3.60 & 8.42 & 7140 & 7.25 & 20.43 & 8790 & 8.98 & 43.59 & 4000 \\
\hline $03 / 10 / 97$ & 10.84 & 32.57 & 8430 & 3.21 & 7.59 & 5940 & 6.30 & 18.45 & 7920 & & & 0 \\
\hline $03 / 26 / 97$ & 9.28 & 27.29 & 7880 & 2.77 & 7.53 & 5570 & 5.05 & 13.73 & 6120 & 7.43 & 33.19 & 3460 \\
\hline $04 / 23 / 97$ & 6.64 & 18.35 & 8930 & 3.30 & 7.37 & 6430 & 5.04 & 15.08 & 9210 & 12.69 & 52.33 & 8280 \\
\hline $05 / 09 / 97$ & 8.10 & 22.43 & 8470 & 3.00 & 7.04 & 6450 & 4.93 & 15.58 & 8310 & & & \\
\hline $06 / 11 / 97$ & 6.35 & 18.32 & 8090 & 1.88 & 4.49 & 4880 & 5.73 & 15.79 & 8730 & 5.68 & 26.90 & 4037 \\
\hline $06 / 25 / 97$ & & & & & $\therefore 7$ & & . & & & 5.64 & 17.02 & 2700 \\
\hline $07 / 01 / 97$ & 7.23 & 18.41 & 11600 & 2.57 & 5.45 & 8390 & 5.11 & 13.89 & 11400 & 9.96 & 39.42 & 8980 \\
\hline $07 / 09 / 97$ & 5.90 & 16.34 & 10500 & 2.06 & $4: 46$ & 6650 & 8.78 & 23.94 & 6290 & 6.37 & 23.94 & 6290 \\
\hline $07 / 16 / 97$ & 5.30 & 14.14 & 11200 & 5.86 & 21.49 & 592 & 5.25 & 14.23 & 11300 & 9.22 & 32.09 & 7890 \\
\hline $09 / 03 / 97$ & 6.26 & 19.53 & 9570 & 2.30 & 6.07 & 7190 & & & 0 & 8.31 & 39.86 & 7020 \\
\hline $11 / 07 / 97$ & 8.16 & 17.42 & 16000 & 2.21 & 4.76 & 9720 & 3.96 & 10.09 & 11900 & 9.02 & 34.11 & 10100 \\
\hline
\end{tabular}

All concentrations in ppmv and normalized by $\mathrm{CO}_{2}$ levels 


\begin{tabular}{|c|c|c|c|c|c|c|c|c|c|c|c|c|}
\hline \multirow[b]{2}{*}{ Date } & \multicolumn{3}{|l|}{ MCB-11 } & \multicolumn{3}{|l|}{$\mathrm{MCB}-13$} & \multicolumn{3}{|l|}{ MCB-14 } & \multicolumn{3}{|l|}{ MCB-15 } \\
\hline & PCE & TCE & $\mathrm{CO}$ & PCE & TCE & $\mathrm{CO} 2$ & PCE & TCE & $\mathrm{CO2}$ & PCE & TCE & $\mathrm{CO2}$ \\
\hline $10 / 07 / 96$ & 2.54 & 18.50 & 12000 & 24.30 & 70.71 & 12100 & 2.32 & 16.62 & 10900 & 10.85 & 40.44 & 8130 \\
\hline $12 / 05 / 96$ & 2.00 & 15.00 & 11600 & 28.04 & 76.58 & 11000 & 1.85 & 11.57 & 11200 & 8.57 & 34.58 & 9370 \\
\hline $01 / 02 / 97$ & 2.30 & 15.20 & 12000 & 28.92 & 79.49 & 11700 & 1.66 & 10.61 & 12100 & 8.54 & 35.43 & 9720 \\
\hline $01 / 30 / 97$ & 1.87 & 13.31 & 11900 & 25.59 & 68.69 & 8770 & 1.08 & 8.63 & 12200 & 6.98 & 26.37 & 8420 \\
\hline $02 / 05 / 97$ & 1.46 & 13.37 & 11400 & 28.85 & 82.23 & 10500 & 0.92 & 8.79 & 11400 & 6.20 & 26.76 & 3980 \\
\hline $02 / 19 / 97$ & 1.45 & 10.89 & 11700 & 20.99 & 63.94 & 8360 & 1.34 & 10.54 & 10900 & 6.19 & 27.97 & 9480 \\
\hline $03 / 10 / 97$ & 0.99 & 10.70 & 12100 & 25.77 & 74.55 & 8430 & 0.69 & $7: 50$ & 11200 & 5.16 & 23.65 & 8080 \\
\hline $03 / 26 / 97$ & 0.98 & 8.52 & 12200 & 23.38 & 65.52 & 7330 & 0.51 & 5.62 & 10300 & 4.45 & 20.33 & 7650 \\
\hline $04 / 23 / 97$ & & & & 32.17 & 84.93 & 10400 & 0.26 & 3.58 & 12900 & 4.59 & 22.14 & 8960 \\
\hline $05 / 09 / 97$ & 0.48 & 7.64 & 13000 & 20.24 & 58.99 & 6300 & 0.24 & 4.23 & 12000 & 3.69 & 18.95 & 7990 \\
\hline $06 / 11 / 97$ & 0.76 & 7.45 & 12900 & 16.79 & 47.48 & 7960 & 0.42 & 4.22 & 11000 & 3.82 & 19.41 & 8820 \\
\hline $06 / 25 / 97$ & & & & 15.72 & 40.36 & 9010 & & $\therefore$ & & & & \\
\hline $07 / 01 / 97$ & 0.94 & 6.53 & 16000 & 27.71 & 66.73 & 12300 & 0.57 & 3.48 & 15400 & & & \\
\hline $07 / 09 / 97$ & 0.93 & 6.26 & 15700 & 22.71 & 57.22 & 12100 & 0.71 & 3.95 & 13800 & 4.06 & 16.90 & 10650 \\
\hline $07 / 16 / 97$ & 0.93 & 6.22 & 15800 & 24.94 & 61.22 & 12800 & 0.63 & 3.32 & 14800 & 4.05 & 17.50 & 10900 \\
\hline $09 / 03 / 97$ & & & 0 & 23.50 & 65.31 & 9160 & & & 0 & & & 0 \\
\hline $11 / 07 / 97$ & 0.70 & 4.33 & 17200 & 20.49 & 49.64 & 11000 & 0.49 & 2.09 & 16500 & 3.01 & 11.88 & 9580 \\
\hline
\end{tabular}

All concentrations in ppmv and normalized by $\mathrm{CO}_{2}$ levels MCB-12: no flow - well clogged 


\begin{tabular}{|c|c|c|c|c|c|c|c|c|c|c|c|c|}
\hline & MCB-16 & & & MCB-17 & & 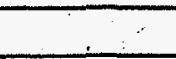 & MCB-19 & & & MCB-20 & & \\
\hline Date & PCE & TCE & $\mathrm{CO2}$ & PCE & TCE & $\mathrm{CO} 2$ & PCE & TCE & $\mathrm{CO} 2$ & PCE & TCE & $\mathrm{CO} 2$ \\
\hline $10 / 07 / 96$ & 4.35 & 26.65 & 10400 & 8.38 & 51.61 & 10300 & 7.56 & 30.93 & 7760 & 6.73 & 40.07 & 11800 \\
\hline $12 / 05 / 96$ & 3.01 & 19.03 & 11100 & 9.10 & 54.00 & 10000 & 5.21 & 22.75 & 5960 & & & \\
\hline $01 / 02 / 97$ & 2.48 & 17.59 & 11800 & 9.09 & 53.94 & 10300 & 9.73 & 25.55 & 1320 & & & \\
\hline $01 / 30 / 97$ & 2.34 & 15.33 & 11900 & 6.84 & 49.07 & 8510 & 3.69 & 20.12 & 6500 & & & \\
\hline $02 / 05 / 97$ & 2.72 & 14.48 & 11100 & 6.19 & 47.49 & 8860 & 5.40 & 20.49 & 5350 & & & \\
\hline $02 / 19 / 97$ & 2.30 & 16.38 & 10900 & 5.37 & 43.53 & 7770 & 2.79 & 11.93 . & 8180 & & & \\
\hline $03 / 10 / 97$ & 1.56 & 12.44 & 11500 & & & 0 & 5.20 & 19.94 & 7590 & & & \\
\hline $03 / 26 / 97$ & 1.05 & 8.45 & 11200 & 5.51 & 43.68 & 8390 & 4.07 & 16.51 & 6640 & & & \\
\hline $04 / 23 / 97$ & 0.83 & 6.65 & 11500 & 4.53 & 35.70 & 10000 & 6.92 & 24.07 & 9630 & & & \\
\hline $05 / 09 / 97$ & 0.94 & 7.27 & 11600 & 4.32 & 36.09 & 9140 & 6.09 & 21.75 & 8830 & & & \\
\hline $06 / 11 / 97$ & 1.01 & 7.65 & 12100 & & & . & 3.82 & 11.00 & 684 & & & \\
\hline $06 / 25 / 97$ & & & & 3.91 & 28.19 & 10600 & & & & 1.19 & 5.18 & 844 \\
\hline $.07 / 01 / 97$ & 1.10 & 6.57 & 15100 & 4.60 & 29.66 & 12300 & & & & 2.72 & 15.96 & 5520 \\
\hline $07 / 09 / 97$ & 1.32 & 7.14 & 15000 & 3.77 & 22.12 & 10200 & 5.21 & 17.55 & 12000 & 0.36 & 17.55 & 12000 \\
\hline $07 / 16 / 97$ & 1.18 & 6.52 & 15600 & 3.20 & 22.27 & 11100 & 6.74 & 16.09 & 977 & 2.84 & 12.67 & 2510 \\
\hline $09 / 03 / 97$ & 0.86 & 6.99 & 12400 & 3.61 & 30.60 & 10100 & 5.38 & 21.35 & 11200 & 2.89 & 18.83 & 4200 \\
\hline $11 / 07 / 97$ & 0.88 & 3.96 & 15900 & 3.27 & 21.74 & 13400 & 4.85 & 15.31 & 14800 & 2.39 . & 13.40 & 5350 \\
\hline
\end{tabular}

All concentrations in ppmv and normalized by $\mathrm{CO}_{2}$ levels MCB-18: no flow - well clogged

MCB-20: sealed for pressure measurements until 6/25/97 


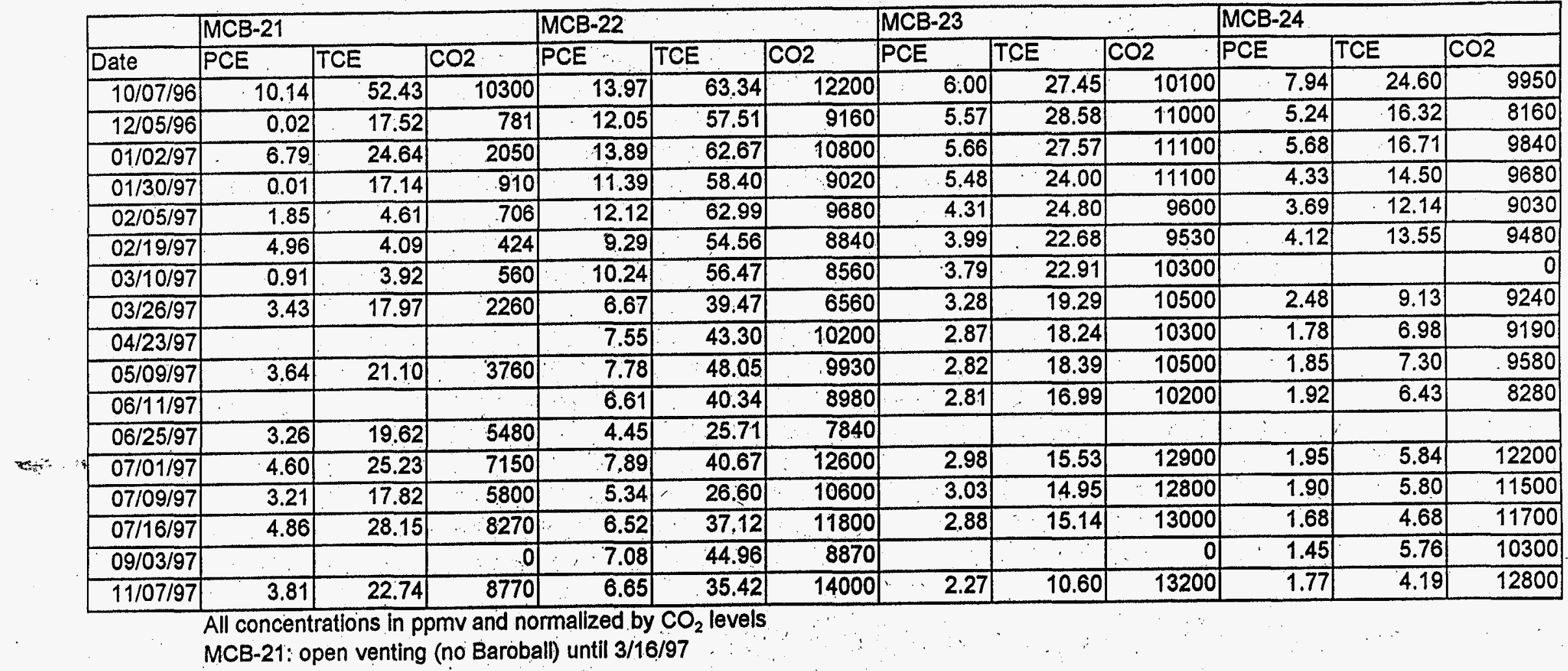




\begin{tabular}{|c|c|c|c|c|c|c|}
\hline & MCB-25 & & i & $\mathrm{MCB}-26$ & & \\
\hline Date & PCE & TCE & $\mathrm{CO} 2$ & PCE. & TCE & $\mathrm{CO2}$ \\
\hline $10 / 07 / 96$ & 14.00 & 42.39 & 7870 & 15.35 & 37.15 & 7170 \\
\hline $12 / 05 / 96$ & 13.77 & 43.08 & 6240 & 12.68 & 25.30 & 4790 \\
\hline $01 / 02 / 97$ & 13.69 & 45.17 & 6960 & 15.63 & 32.12 & 7510 \\
\hline $01 / 30 / 97$ & 10.59 & 35.87 & 5520 & 10.43 & 22.49 & 4370 \\
\hline $02 / 05 / 97$ & 9.90 & 38.48 & 6050 & 12.15 & 25.38 & 5800 \\
\hline $02 / 19 / 97$ & 9.85 & 37.92 & 6360 & 11.82 & 23.56 & 6160 \\
\hline $03 / 10 / 97$ & 9.51 & 37.61 & 6190 & 11.54 & 22.19 & 5880 \\
\hline $03 / 26 / 97$ & 7.99 & 31.58 & 5620 & 8.80 & 18.17 & 5230 \\
\hline $04 / 23 / 97$ & & - & & 11.00 & 21.17 & 8630 \\
\hline $05 / 09 / 97$ & 8.59 & 36.90 & 6790 & 10.51 & 19.89 & 6930 \\
\hline $06 / 11 / 97$ & 5.43 & 23.38 & 5180 & 8.57. & 18.50 & 5260 \\
\hline $06 / 25 / 97$ & & $\because$ & $\therefore \quad \vdots$ & & $\because$ & \\
\hline $07 / 01 / 97$ & 8.65 & 32.85 & 9060 & 12.68 & 21.62 & 10600 \\
\hline $07 / 09 / 97$ & 7.58 & 29.41 & 8140 & 10.83 & 18.47 & 8610 \\
\hline $07 / 16 / 97$ & 8.93 & 30.54 & 8880 & 14.89 & 22.95 & 3530 \\
\hline $09 / 03 / 97$ & & & 0 & 12.49 & 25.09 & 8820 \\
\hline $11 / 07 / 97$ & 5.45 & 17.81 & 4870 & 10.01 & 17:10 & 10500 \\
\hline
\end{tabular}

